\title{
Image-Guided Ablation for Colorectal Liver Metastasis: Principles, Current Evidence, and the Path Forward
}

\author{
Yuan-Mao Lin ${ }^{1} \mathbb{D}$, Iwan Paolucci ${ }^{1} \mathbb{D}$, Kristy K. Brock ${ }^{2}$ and Bruno C. Odisio ${ }^{1, *(\mathbb{D})}$ \\ 1 Department of Interventional Radiology, Division of Diagnostic Imaging, The University of Texas MD \\ Anderson Cancer Center, Houston, TX 77030, USA; ylin22@mdanderson.org (Y.-M.L.); \\ IPaolucci@mdanderson.org (I.P.) \\ 2 Department of Imaging Physics, Division of Diagnostic Imaging, The University of Texas MD Anderson \\ Cancer Center, Houston, TX 77030, USA; kkbrock@mdanderson.org \\ * Correspondence: bcodisio@mdanderson.org; Tel.: +1-713-563-7066
}

check for updates

Citation: Lin, Y.-M.; Paolucci, I.; Brock, K.K.; Odisio, B.C. Image-Guided Ablation for Colorectal Liver Metastasis: Principles, Current Evidence, and the Path Forward. Cancers 2021, 13, 3926. https://doi.org/10.3390/ cancers13163926

Academic Editor: Constantinos T. Sofocleous

Received: 9 June 2021

Accepted: 2 August 2021

Published: 4 August 2021

Publisher's Note: MDPI stays neutral with regard to jurisdictional claims in published maps and institutional affiliations.

Copyright: (c) 2021 by the authors. Licensee MDPI, Basel, Switzerland. This article is an open access article distributed under the terms and conditions of the Creative Commons Attribution (CC BY) license (https:// creativecommons.org/licenses/by/ $4.0 /)$.
Simple Summary: Colorectal cancer is the fourth most common type of cancer globally. Approximately $20 \%$ of patients with colorectal cancer present with synchronous liver metastases, and up to $60 \%$ will develop metachronous metastases during the course of the disease. Although liver resection is currently considered the local treatment of choice for colorectal liver metastasis (CLM), less than one-third of patients are eligible for surgery at the time of diagnosis of CLM. Ablation is a well-established, less invasive, locoregional therapy for patients with small CLMs, which has shown favorable oncological outcomes in patients with unresectable CLMs, comparable to those in patients eligible for surgery. The increasing knowledge of factors affecting oncological outcomes has allowed selected patients with resectable small volume CLMs to be treated with thermal ablation with curative intent. The continuous technological evolutions in imaging and image guidance have contributed to this paradigm shift in CLM treatment. The importance of patient selection, patient factors, tumor factors, ablation techniques, and clinical applications is discussed in this article.

Abstract: Image-guided ablation can provide effective local tumor control in selected patients with CLM. A randomized controlled trial suggested that radiofrequency ablation combined with systemic chemotherapy resulted in a survival benefit for patients with unresectable CLM, compared to systemic chemotherapy alone. For small tumors, ablation with adequate margins can be considered as an alternative to resection. The improvement of ablation technologies can allow the treatment of tumors close to major vascular structures or bile ducts, on which the applicability of thermal ablation modalities is challenging. Several factors affect the outcomes of ablation, including but not limited to tumor size, number, location, minimal ablation margin, $R A S$ mutation status, prior hepatectomy, and extrahepatic disease. Further understanding of the impact of tumor biology and advanced imaging guidance on overall patient outcomes might help to tailor its application, and improve outcomes of image-guided ablation.

Keywords: colorectal liver metastasis; radiofrequency; irreversible electroporation; microwave; ablation; cryoablation; survival; local tumor progression

\section{Introduction}

Colorectal cancer is the fourth most common malignancy and the third leading cause of cancer-related death in the world [1]. Approximately $20 \%$ of patients with colorectal cancer present with synchronous liver metastases, and up to $60 \%$ will develop metachronous metastases during the course of the disease [2]. The liver is the most common site of metastases, and liver metastases are negatively associated with overall survival [2]. Liver resection is currently considered the local treatment of choice for colorectal liver metastasis (CLM), with reported 5-year overall survival rates of up to 58\% in selected patients [3]. However, only $20-30 \%$ of patients are eligible for resection, based on the patient's medical 
status and the extent of the disease [4]. Ablation is a well-established locoregional therapy for patients with small CLMs. Additionally, ablation has shown encouraging results for potentially resectable CLMs [5-8]. An ongoing randomized study is investigating the use of ablation as a first-line local approach for the treatment of CLM [9]. The role of ablation is increasing, and the treatment paradigm of CLM patients is evolving. This article aims to review the role of ablation, as well as to discuss the future directions of this treatment modality on the management of patients with CLM.

\section{Patient Selection}

The introduction of novel target agents along with evolving chemotherapy regimens has been linked with significant improvements in the outcomes of patients with CLM, as reflected in increased median survival up to 31 months in selected patients with unresectable CLM [10-13], as well with the conversion of CLM patients deemed unresectable to resectable. Despite such advances, systemic chemotherapy is considered a palliative treatment, unless the patients can undergo resection or ablation and their derived benefits [14]. In this context, liver ablation has been utilized in a wide variety of clinical presentations, ultimately aiming to provide a local curative-intent option for patients with liver-only or liver-dominant colorectal metastasis.

Commonly, ablation is applied for patients who present with small and limited CLMs. Image-guided ablation is particularly effective in treating small- to medium-sized tumors. The most commonly used cutoff maximal diameter is $3 \mathrm{~cm}$, as a tumor size up to $3 \mathrm{~cm}$ is an independent predictor for oncological outcomes that can be compared to outcomes of surgical resection [15-17]. For tumors measuring up to $5 \mathrm{~cm}$, complete tumor eradication can be achieved, depending on proper anatomical location and multiple overlapping ablations [7,18]. Image-guided ablation is generally not recommended for tumors larger than $5 \mathrm{~cm}$, given high rates of local tumor progression (LTP) $[7,19]$. Universally, a small solitary CLM is ideal for image-guided ablation, with 5-year overall survival rates up to $51 \%[14,20]$. However, patients with up to five tumors are also eligible for image-guided ablation [14]. For tumor size $\leq 3 \mathrm{~cm}$, number $\leq 3$, and no extrahepatic disease, imageguided ablation with ablation margins $>10 \mathrm{~mm}$ has been shown to offer similar local tumor control to hepatectomy alone [21]. The use of ablation on patients with liver-only resectable CLMs up to $3 \mathrm{~cm}$ varies among institutions; some reserve it for patients who refused surgery, while others apply ablation as the first local modality-along with the "test-oftime" concept-with the aim of treating the disease while limiting the number of liver resections performed on patients who might ultimately develop additional metastases [22] Ablation may even become the preferred go-to local treatment, depending on the results of a phase III randomized controlled trial comparing liver resection to thermal ablation for patients presenting with CLMs up to $3 \mathrm{~cm}$, with expected results in $2025[9,23]$.

Tumor location can affect both local tumor control and complications. Care should be taken when performing ablation on tumors located next to central bile ducts, vessels, or other vulnerable structures that cannot be protected with hydrodissection or other protective techniques. The use of thermal ablation to treat tumors adjacent to the central bile ducts has been associated with increased risk of bile duct injury and subsequent complications, such as cholangitis or liver abscess. It has been reported that patients with prior use of intrahepatic chemotherapy or bevacizumab, as well with pre-existing biliary dilatation, are at higher risk of developing biliary complications [24,25]. Thermal ablation close to large vessels increases the risk of residual tumor and early LTP due to the heat-sink phenomenon, as well as venous thrombosis and, consequently, liver infarction [26-29]. In such situations, non-thermal ablation techniques such as irreversible electroporation (IRE) can be applied [30,31]. Additionally, more intensive ablation strategies or the use of microwave ablation (MWA) should be considered to compensate for the heat-sink phenomenon. Studies have demonstrated that MWA is effective on perivascular tumors with satisfactory ablation margins [21,32]. Although the optimal patient for ablation is one with disease limited to the liver, ablation can benefit patients with limited extrahepatic dis- 
eases $[20,33,34]$. Palliative liver ablation in patients with extensive extrahepatic metastases is not currently recommended.

Image-guided ablation is recommended as a safe and effective locoregional therapy for CLM patients [15,35-37]. Ablation combined with systemic chemotherapy has been shown in a prospective randomized phase II study to significantly prolong the overall survival in patients with unresectable CLMs when compared to the use of chemotherapy alone [38]. Hepatectomy combined with intraoperative or postoperative ablation can achieve local tumor control and preserve the remaining liver in patients who have limited liver reserves, such as those with extended liver distribution or previous major liver resection [39-41]. Furthermore, postoperative ablation can be used to treat CLMs that were not able to be identified during intraoperative ultrasound evaluation. In such circumstances, cross-sectional (CT or MR) guided ablation has been shown to be an effective and safe approach [42]. For recurrent and new tumors, it is preferable to use image-guided ablation to treat them repeatedly, while limiting the destruction of the liver parenchyma and providing survival rates similar to patients without recurrence [43-46]. Moreover, imageguided ablation is considered to be the treatment of choice in patients with technically resectable disease who cannot undergo surgery due to medical comorbidities. Several publications have reported that ablation leads to lower post-treatment morbidity, lower complication rates, and shorter hospital stays. Repeat ablation can also be utilized as a "test-of-time" strategy, in order to reduce unnecessary metastasectomy on patients with poor tumor biology [22,47]. This so-called "test-of-time" strategy offers thermal ablation ahead of liver resection, and is advocated for patients with small tumors in order to spare surgically eligible patients who would develop extended liver disease from potentially unnecessary liver resection or remain disease-free after ablation [22,47]. Those with local failure who remain candidates for local therapy can still be treated by hepatectomy if and when ablation fails locally $[22,47]$.

\section{Technique}

\subsection{Ablation Modalities}

Radiofrequency ablation (RFA) and MWA ablations are thermal ablation modalities that are widely used as the standard of care to treat CLM. Moreover, IRE has been applied for patients who are not amenable to thermal ablation due to the higher risk of thermal injury to vital structures-such as central bile ducts-in proximity to the ablation zone.

\subsubsection{Radiofrequency Ablation}

This widely available technique uses an interstitial electrode to produce an alternating electric current to the target tissue. The electric current oscillates tissue ions rapidly and creates frictional heating. When the temperatures of the target tissue are between $60{ }^{\circ} \mathrm{C}$ and $100{ }^{\circ} \mathrm{C}$, protein denaturation, coagulative necrosis, and immediate cell death occur. The electrical conductance is degraded above $100{ }^{\circ} \mathrm{C}$ due to the water vaporization and tissue carbonization, limiting the amount of energy that can be delivered to eradicate the tumor, and resulting in a suboptimal treatment effect. A major limitation of RFA is the heat-sink effect that occurs if the target lesion abuts a blood vessel larger than $3 \mathrm{~mm}$. Another disadvantage is the thermal injury to vital structures adjacent to the ablated area, such as bile ducts and vessels. For this reason, applying RFA to tumors close to central bile ducts and vessels is challenging, and sometimes contraindicated, because of suboptimal local tumor control and higher rates of complications [48,49].

\subsubsection{Microwave Ablation}

This technique creates an electromagnetic spectrum with frequencies from 900 to $2450 \mathrm{MHz}$ that generate heat by agitating surrounding water molecules. Theoretically, MWA generates greater heat and less heat-sink effect than RFA, creating larger ablation zones in a shorter period. Studies have reported that MWA is more effective than RFA for perivascular tumors $[21,32,50,51]$. For peribiliary tumors, the complication rates are higher 
for MWA than for RFA (57 vs. 3\%; $p=0.002$ ) [50]. Retrospective studies have reported that MWA leads to lower rates of LTP than RFA (MWA: 6-10\% vs. RFA: 20-20.3\%) and a lower 2-year cumulative local recurrence rate (7 vs. $18 \%$; $p=0.01$ ) [52-54]. However, another study reported no difference in the cumulative local tumor recurrence rates between MWA and RFA after stratifying outcomes by ablation margin size [21]. Regarding overall survival and ablation-related complications, there was no significant difference between MWA and RFA in the above literature [21,52-54]. For treating primary and metastatic liver tumors, a meta-analysis comparing MWA and RFA reported no significant differences in overall survival, disease-free survival, local recurrence rates, or adverse events [55]. There are no randomized studies comparing MWA to RFA, and it may be that the two techniques have complementary rather than competing roles.

\subsubsection{Cryoablation}

Cryoablation uses extreme cold generated by the Joule-Thomson effect to freeze and destroy tumors. The features of cryoablation are the repetition of the freeze-thaw cycles. The rapid freezing first forms extracellular ice, causing a hyperosmotic state that draws the intracellular free water and causes damage to the cell; as temperatures drop, intracellular ice forms, causing further damage. This is followed by a slow thaw cycle, in which ice melts and water enters the cell, causing expansion and disruption to the cell. Although cryoablation was one of the earliest ablation techniques used to treat CLM, it has been associated with higher rates of local recurrence and complications [56], and is therefore rarely applied in clinical practice. A study of 212 patients including 77 patients with CLM treated by percutaneous cryoablation showed the 3-year LTP rate was $21.6 \%$, and the 5-year overall survival rate was around 20\% for CLM [57]. The overall complication rate was $5.8 \%$ in the whole cohort of 212 patients, including acute respiratory distress syndrome and cryoshock. The cryoshock presented with multiorgan failure and disseminated intravascular coagulation, which was presented in three patients, contributing to death.

\subsubsection{Irreversible Electroporation}

IRE is a novel non-thermal ablation technique. The mechanism of IRE is based on high-voltage electrical pulses that cause irreversible cellular membrane disruption, leading to cell death while keeping the underlying connective tissue scaffold intact. This technique keeps structures that are vulnerable to thermal injuries-such as blood vessels and bile ducts-intact. Because IRE does not use heat to eradicate the tumors, its efficacy is not impeded by the heat-sink effect on adjacent blood vessels [58]. IRE must be applied under general anesthesia, with complete muscle relaxation and ECG synchronization during IRE delivery [59]. A small case series study reported that luminal narrowing was noted in in $27.7 \%(15 / 55)$ of bile ducts within a $1-\mathrm{cm}$ radius of the ablation defect [31]. The primary efficacy of IRE ranges from 66 to $100 \%$ for hepatic tumors in proximity to major vascular or biliary structures [30,60-64]. The main limitation of IRE is that the ablation zone is created between two parallel electrodes spaced approximately $1-1.5 \mathrm{~cm}$ apart, which is relatively small compared to other techniques. The required precise placement of multiple electrodes in parallel with appropriate space is also challenging and timeconsuming $[65,66]$. However, stereotactic guidance has been shown to be able to overcome these issues, significantly reducing procedure length and improving electrode placement accuracy [67]. For the evaluation of post-IRE ablation imaging, it has been reported that the imaging response may be inaccurate in the reflection of the histopathological appearance of the ablation zone, which limits the evaluation and efficacy of the treatment response $[68,69]$.

Two retrospective studies found 2-year overall survival rates of up to $62 \%$ in CLM patients treated with IRE, and the 2-year progression-free survival was $18-40.5 \%$ [70,71]. Another study of 24 patients with unresectable CLM showed 3- and 5-year overall survival rates of $25 \%$ and $8.3 \%$, respectively [62]. Recently, a phase II, single-arm clinical trial of unresectable CLM near critical structures reported a local control rate after 1 year 
following repeat IRE of $74 \%$, and the overall complication rate was $40 \%$ [72]. Although this complication rate was substantially higher than most reports for the thermal ablation of CLM in less challenging locations, the authors inferred that most of the procedures having been performed simultaneously with surgery might be the cause of the high complication rate and not all of the reported adverse events were directly related to the IRE. Although the current evidence is encouraging, no current randomized controlled trials compare IRE with standard therapy. Moreover, the relatively higher rates of LTP with this technology might reflect the selection of tumors that are more challenging to treat due to their proximity to major bile ducts and vascular structures. Further randomized controlled trials comparing IRE with other standard treatments are warranted.

\subsection{Imaging Guidance Techniques}

Ultrasound, computed tomography (CT), magnetic resonance imaging (MRI), and positron emission tomography (PET) are utilized for liver ablation imaging guidance. Each modality has its strengths and weaknesses. Imaging fusion techniques for combining multiple modalities have also been developed for treatment planning, tumor targeting, and ablation margin assessment.

Pre-ablation imaging plays a critical role in patient selection and treatment planning [73]. A baseline intravenous contrast-enhanced CT scan of the chest, abdomen, and pelvis is commonly used in the workup of patients considered for ablation [74]. A wholebody fluorodeoxyglucose (FDG) PET/CT scan can provide additional information for better quantification of liver and extrahepatic metastases, and may change the management [75]. MRI is the most accurate imaging for the detection and characterization of hepatic metastases, especially with the hepatocyte-specific MRI contrast agent; it has a high sensitivity for the detection of smaller tumors that may not be easily detected by CT and PET [76]. The NCCN guidelines recommend that intravenous contrast-enhanced CT is the minimal requirement if liver-directed treatment is contemplated, and a hepatic MRI with intravenous extracellular or hepatobiliary gadolinium-based contrast agents is preferred over CT to assess the exact number and distribution of metastases [77].

\subsubsection{Computed Tomography}

The advantages of $\mathrm{CT}$ are wide availability and decreased operator dependence. The intravenous contrast agent can be administered at the time of applicator placement to better localize the lesions. Using CT fluoroscopy can provide a nearly real-time visualization of applicator placement. An immediate post-ablation contrast-enhanced CT can be used to provide a rapid evaluation of ablation margins and residual tumors. The disadvantages of $\mathrm{CT}$ guidance include the ionizing radiation and the limitations of guidance planes.

\subsubsection{Magnetic Resonance Imaging}

The advantages of MRI guidance include non-ionizing radiation, higher tissue contrast resolution, and multiparametric imaging. This allows for radiation-free near-real-time imaging during applicator placement [78]. Additionally, MRI is the only modality with well-validated techniques for near-real-time temperature monitoring during the ablation, which is useful to delineate the ablation zone [79]. The limitations of MRI guidance are the complexity of the procedure due to the use of only MR-compatible devices, limited availability, and relatively high cost.

\subsubsection{Ultrasound}

Ultrasound can provide real-time monitoring of applicator placement without ionizing radiation. Although it is occasionally difficult to delineate the lesions due to its limited sensitivity and operator-dependent nature, using an intravenous contrast can improve the sensitivity, similarly to the contrast-enhanced CT $[80,81]$. A post-ablation contrast-enhanced ultrasound can provide an immediate evaluation of residual tumors and guidance for supplementary ablation [80]. One of the limitations of using ultrasound is that the gas 
bubbles generated during the RFA or MWA can obscure the visualization of the applicator and lesions.

\subsubsection{PET}

The advantage of PET in ablation guidance is it can offer metabolic information during the procedure. Several studies have reported that PET can identify LTP following ablation earlier than intravenous contrast-enhanced CT before morphological changes, and PET/CT is currently recommended for the assessment and follow-up of patients with CLMs undergoing ablation [82-84]. However, there are challenges in the registration of images due to the morphological distortion after the ablation. Additionally, the FDG activity of tumors is not dissipated by ablation, and the ablation-related inflammatory changes can lead to difficulty in the assessment of residual tumors [85]. A split-dose technique for FDG PET/CT guidance has been developed to overcome these limitations [86]. The main concept of this technique is that a smaller first dose of FDG before the ablation will be significantly decayed by the time the second, larger dose is administered, allowing for the detection of FDG activity within any residual viable tumor. Another technique using intraprocedural nitrogen 13 ammonia perfusion PET has been developed to assess the ablation margins [87].

\subsection{Stereotactic and Robotic Guidance}

Stereotactic and robotic guidance systems have been used to facilitate the placement of the ablation applicator in real time [88,89], enhance the target visibility through image fusion [90], and improve the operator's spatial orientation. Stereotactic guidance can be performed with electromagnetic or optical tracking systems. The instruments are guided either freehand, using an aiming device, or with the assistance of a robotic arm [91]. The most common imaging modalities used are three-dimensional (3D) CT and ultrasound, with developments towards the coupling of fluoroscopy and 3D imaging from C-arm cone-beam CT [92-94]. There is evidence from randomized trials showing that stereotactic or robotic guidance improves the accuracy of needle placement compared to conventional image guidance-especially when using off-plane trajectories $[95,96]$. In addition, it has been shown that the radiation dose in CT-guided ablation could be reduced using such devices $[97,98]$.

\section{Factors Affecting Ablation Outcomes}

The increasing knowledge of factors affecting oncological outcomes after ablation has allowed CLM to be treated by ablation, with curative potential. Local tumor control of the ablated tumor is the main goal for effective ablation. Although ablation has a favorable curative potential for CLM, it has been associated with a higher risk of local recurrence when compared to surgical resection $[14,99]$. The desirable low LTP rates are associated with local disease control and disease-free survival, which might eventually affect overall survival.

\subsection{Tumor Factors}

Studies of LTP and survival show an advantage for small tumor size [15,37]. A tumor size up to $3 \mathrm{~cm}$ is an independent predictor of overall and LTP-free survival, and provides similar oncological outcomes to resection [15-17,100]. In a study of 233 CLM patients treated with RFA, tumors $\leq 3 \mathrm{~cm}$ in size had better LTP rates (44 vs. $78 \% ; p<0.001)$ and median overall survival (41 vs. 25 months; $p=0.005$ ) [15]. Similar results were found in another study of 210 patients with CLM treated with MWA. Lower recurrence rates (47.9 vs. $66.2 \% ; p<0.001)$ and longer median overall survival (48.3 vs. 25.6 months; $p<0.001)$ were shown in patients with tumor size $\leq 3 \mathrm{~cm}$ [101]. For tumors of 3-5 cm in size, ablation can be considered with multiple overlaps to achieve complete ablation. Thermal ablation is generally not recommended for a curative intent to treat tumors larger than $5 \mathrm{~cm}$ because of the high local recurrence rate $[7,19]$. However, ablation of CLMs up to $5 \mathrm{~cm}$ in size can 
be performed with adequate planning and monitoring in selected cases, with acceptable outcomes [44,89].

The location of the tumor also affects local tumor control and complications. Ablation of tumors adjacent to central bile ducts using thermal ablation techniques is associated with increased risk of bile duct injury and subsequent complications, such as cholangitis or liver abscess [26]. The risk of tumor recurrence is increased in thermal ablation close to a large vessel (the heat-sink phenomenon), and warrants intensive treatment strategies $[20,27,28]$. In such circumstances, the non-thermal ablation technique IRE has a role in the treatment of tumors abutting central bile ducts and vessels $[33,102]$.

\subsection{Patient Factors}

Mutation of the RAS gene family (KRAS, NRAS and HRAS) is one of the relevant prognostic biomarkers for locoregional CLM treatment [103-106]. Mutations in the RAS gene family are present in up to $40 \%$ of patients with colorectal cancers [107]. Generally, patients with RAS-mutated CLM have worse survival than those with wild-type $R A S[108,109]$. Various studies have disclosed that patients with mutant $R A S$ have earlier LTP and worse overall survival $[103,105,106]$. One study analyzed 92 patients with $137 \mathrm{ab}-$ lated CLMs, and reported that those with mutant RAS had worse 3-year LTP-free survival than those with wild-type RAS (35 vs. 71\%; $p<0.001$ ) [104]. Additionally, RAS mutation was associated with earlier LTP in the ablated CLMs [104]. A two-institutional analysis of 136 patients with 218 ablated CLMs showed that achieving minimal ablation $>10 \mathrm{~mm}$ can significantly improve the LTP among patients with mutant RAS. The 3-year LTP-free survival rates of mutant $R A S$ CLM were $29 \%$ for ablation margins $>10 \mathrm{~mm}$ and $48 \%$ for $\leq 10 \mathrm{~mm}(p=0.038)$ [103] (Figure 1).

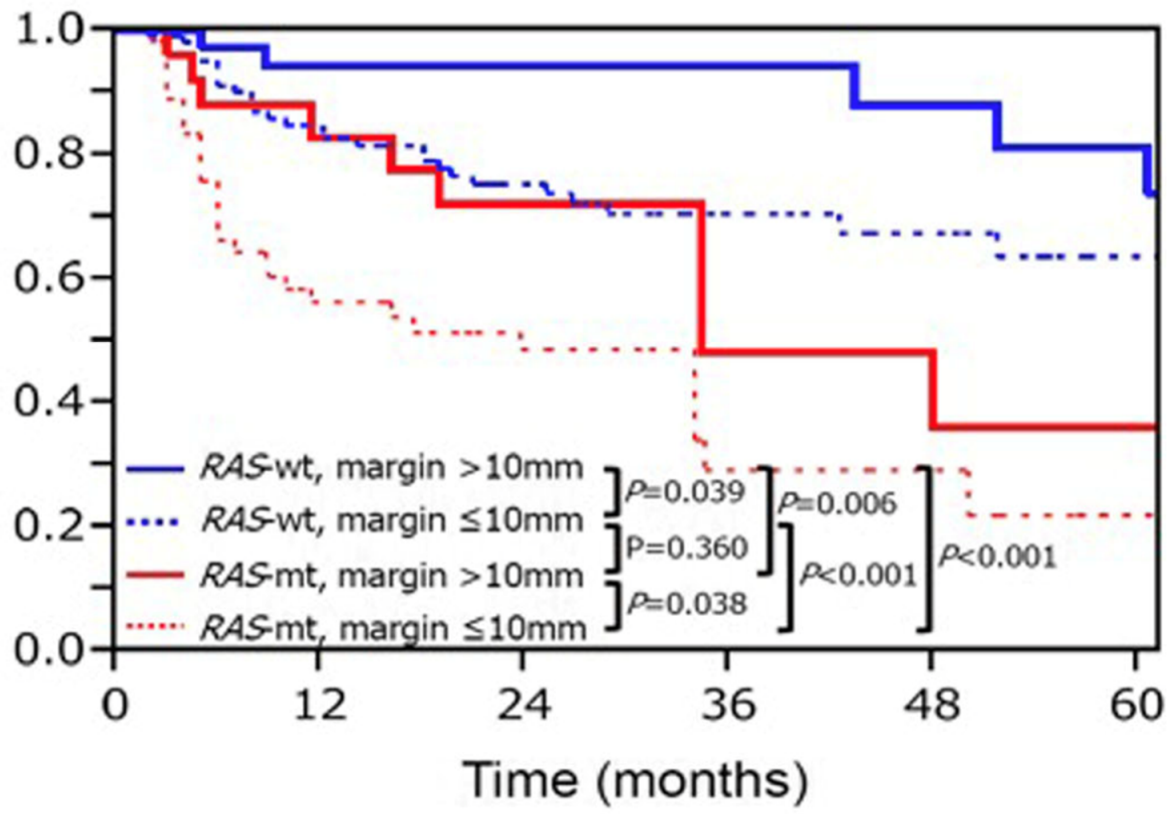

Patients at risk

RAS-wt, margin $>10 \mathrm{~mm} \quad 35$

RAS-wt, margin $\leq 10 \mathrm{~mm}$

RAS-mt, margin $>10 \mathrm{~mm}$

RAS-mt, margin $\leq 10 \mathrm{~mm}$

$$
103
$$

55

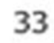

79

17

28

24
51
13
17

20
28
6
6

14

21

4

5
12

11

3

2

Figure 1. The RAS mutant status and the ablation margin are two important factors of LTP-free survival in CLM treatment with ablation. Reproduced with permission from Marco Calandri et al., European Radiology; published by Springer, 2018 [103]. 
Another study reported that the risk of LTP was 15.6-fold in mutant RAS with an ablation margin of 1-5 mm compared with wild-type $R A S$ with an ablation margin of $\geq 6 \mathrm{~mm}$ [105]. Additionally, KRAS mutation was an independent predictor of shorter overall survival, time to the new liver, and peritoneal metastases. According to these studies, a minimal ablation margin of $>10 \mathrm{~mm}$ should be acquired to achieve acceptable oncological outcomes, especially for mutant $R A S$ tumors.

Beyond RAS alteration, other genetic alterations have prognostic utility in the treatment of CLM. Those include BRAF, TP53, SMAD4, and microsatellite instability [110]. Moreover, the double mutations of TP53 with either KRAS, NRAS, or BRAF were associated with significantly worse survival compared with mutations in both gene groups alone in patients undergoing liver resection [111]. Coexisting mutations in RAS, TP53, and $S M A D 4$ were associated with significantly worse recurrence-free and overall survival than coexisting mutations in any two or one of these genes [112]. However, the evidence of these genetic profiles affecting the ablation outcomes is currently lacking.

The embryonic origin of the primary tumor can impact the oncological outcomes of patients with CLM treated by ablation. It has been reported that patients with primary tumors originating from the midgut region had worse survival when compared to patients with hindgut origin colorectal cancer $[113,114]$. In a study of 74 patients undergoing percutaneous thermal ablation, the 3-year recurrence-free survival and overall survival rates were $24 \%$ and $40 \%$, respectively, for hindgut origin, and $5.6 \%$ and $8.3 \%$, respectively, for midgut origin [113]. In this study, the patients with midgut-origin tumors had less local therapy in case of metastatic recurrence, inferring that the recurrence of midgut-origin tumors was more aggressive.

Moreover, prior history of liver resection was associated with local tumor control and survival after ablation of CLM. It has been reported that 3-year LTP-free survival (73 vs. $34 \% ; p<0.001$ ), recurrence-free survival (23 vs. $9.1 \% ; p=0.026$ ), and overall survival (78 vs. $48 \% ; p=0.003$ ) were improved in patients with prior hepatectomy when compared to patients without history of prior hepatectomy for CLM [115]. The authors of this study speculated that the better oncological outcomes were attributed to the patient selection for initial hepatectomy, in which tumor characteristics are more favorable. According to these results, ablation can serve as an effective therapy for patients who present with newly developed CLM after liver resection.

Several patient and disease characteristics predicting clinical outcomes after thermal ablation could be used for patient stratification. An ablation clinical risk score adapted from surgical clinical risk score-including the nodal status of the primary tumor, the time interval from primary resection to CLM diagnosis, carcinoembryonic antigen level, number of tumors, and size of the largest tumor-is associated with local tumor control and overall survival $[15,47,116]$.

For patients with extrahepatic disease, ablation can provide benefit to patients with limited and treatable extrahepatic diseases $[34,117,118]$. The patients with lung-only metastases had the highest median overall survival when compared with those with metastases at more than one site ( 35 months and 14 months, respectively) in a study of CLM treated with RFA [15]. The results were similar to a surgical report showing that patients who had only lung metastases had higher median overall survival compared with those with multiple metastatic sites (46 months and 15 months, respectively) in patients undergoing liver and extrahepatic disease resection [117].

\subsection{Technique Factors}

Several studies have shown the ablation margin as a key factor associated with local tumor control $[15,25,37,119]$. Minimal ablation margins larger than $5 \mathrm{~mm}$ in a 3D plane are associated with optimal local tumor control $[15,37,119]$. A panel of experts has recommended minimal ablation margins larger than $10 \mathrm{~mm}$ as a procedure goal for patients with CLM [14]. In a case series of 73 patients with 94 CLM tumors, the two-year LTP rates for tumors with $0-, 1-5-, 6-10-$, or 11-15-mm minimal ablation margins were 74 , 
54,26 , and $20 \%$, respectively $(p=0.011)$ [119]. In a recent report, the LTP rate for tumors with $>10 \mathrm{~mm}$ ablation margins was 5\%, compared to $90 \%$ and $60 \%$ for margins of 0 and $1-5 \mathrm{~mm}$, respectively [15]. Nevertheless, achieving minimal ablation margins of $>10 \mathrm{~mm}$ is a challenging task. From the published case series, the number of ablated CLM tumors with minimal ablation margins $>10 \mathrm{~mm}$ was less than $30 \%[15,103,119]$. In contrast to liver resection, pathological determination of a margin-negative ablation cannot be made after most cases of image-guided ablation. However, ablation with negative biopsy findings of the margin and center of the ablation zone, and with ablation margins $\geq 5 \mathrm{~mm}$, carries a cumulative incidence rate of LTP of $3 \%$ at 2 years, which is comparable to reported marginal recurrence after R0 resections for CLM [120,121]. Moreover, the negative biopsy findings were positively associated with ablation margins, indicating that achieving larger margins is comparable to complete resection. Nevertheless, the conventional method of measuring the ablation margins is by manual measurement with anatomic landmarks on post-ablation contrast-enhanced cross-sectional imaging [119]. This is limited by the misalignment of the liver due to the patient's position and respiratory phases, tissue structural changes after ablation, and the image resolution. Some techniques using the non-rigid registration of pre- and post-ablation CT or MR imaging aim to solve the problem of misalignment and exploit perfusion PET or 3D software to facilitate the assessment of minimal ablation margins $[81,87,122,123]$; however, to date, no technique has been established as a reliable and objective source of intraprocedural information, warranting further investigation.

Accurate ablation applicator placement is a prerequisite during image-guided ablation. Stereotactic image-guidance systems have been proven to provide accurate 3D applicator placement to complete the tumor coverage $[95,96]$. This also allows for the placement of multiple applicators to cover the whole tumor with multiple overlapping ablation zones [89]. Some studies have reported that stereotactic image guidance can improve the primary efficacy of liver tumor ablation [98].

The precise tumor localization and conspicuity are important factors for successful image-guided ablation. It has been reported that transcatheter CT arterial portography and CT hepatic arteriography can improve the conspicuity of hepatic tumors during ablation [124]. A study of 108 patients with CLM submitted to 156 percutaneous thermal ablation procedures showed that CT hepatic arteriographic guidance was associated with significantly superior local tumor control compared with conventional CT fluoroscopic guidance. The 2-year LTP-free survival was $8.9 \%$ for CT hepatic arteriography and $32.8 \%$ for CT fluoroscopy $(p<0.001)$ [125].

The role of anesthetic techniques in ablation is critical, since they reduce the patient's pain, anxiety, and movements during the procedure and facilitate the achievement of an adequate localization, resulting in a successful ablation [126]. Several anesthetic methods are used, such as general anesthesia, and sedation using fentanyl, midazolam, or propofol. Ideally, general anesthesia is preferred because of controllable respiration during the procedure, potentially allowing for more accurate ablation applicator placement and consequent ablation zones. For respiratory motion, high-frequency jet ventilation-a mechanical ventilation method-is applicable to decrease respiratory motion during liver ablation [127]. Nevertheless, sedation with propofol can provide equivalent oncological outcomes to general anesthesia. It has been reported that sedation with propofol and general anesthesia for percutaneous liver ablation are associated with better local tumor control than sedation with midazolam, providing LTP rates of $4.3 \%(4 / 94), 5.7 \%(2 / 35)$, and $45.2 \%(19 / 42)$, respectively $(p<0.001)$ [128].

\section{Clinical Applications: Current Evidence}

\subsection{Patients Ineligible for Resection}

Ablation has been used as a safe and effective treatment in patients with CLM initially ineligible for surgery $[15,35-37]$ (Table 1). Patients who are ineligible for surgery comprise a significant portion of the present literature on the use RFA for CLM, with the 5-year overall survival rate ranging from $17 \%$ to $51 \%[15,36,129,130]$. To date, only one randomized con- 
trolled trial has compared systemic chemotherapy with or without radiofrequency ablation, in which 119 patients with unresectable CLM were included [38,131]. In this phase II trial, patients with extrahepatic disease, more than 10 liver metastases, more than $50 \%$ liver involvement, and maximal tumor size of more than $4 \mathrm{~cm}$ were excluded. The study showed a significant improvement in terms of overall survival and progression-free survival for patients treated with combined treatment (RFA plus systemic chemotherapy). At a median follow-up of 9.7 years, the 8-year overall survival and progression-free survival rates were $35.9 \%$ and $22.3 \%$ for combined treatment, and $8.9 \%$ and $2.0 \%$ for systemic chemotherapy alone, respectively. It should be highlighted that almost half of the patients received RFA plus liver resection. Nevertheless, this trial seems to provide evidence that pursuing aggressive local treatment of CLM can prolong OS in patients with unresectable CLM.

Table 1. Relevant published studies on survival following ablation of colorectal liver metastases initially ineligible for resection alone within 10 years.

\begin{tabular}{|c|c|c|c|c|c|c|c|c|c|c|}
\hline Author/Year & $\begin{array}{l}\text { Type of } \\
\text { Study }\end{array}$ & Intervention & Approach & $\begin{array}{c}\text { Number of } \\
\text { Patients/Lesions }\end{array}$ & $\begin{array}{c}\text { Mean/Median } \\
\text { Tumor } \\
\text { Size }(\mathrm{cm})\end{array}$ & $\begin{array}{c}\text { Mean/Median } \\
\text { Tumor } \\
\text { Number }\end{array}$ & $\begin{array}{l}\text { Median } \\
\text { Follow-Up } \\
\text { Period in } \\
\text { Months }\end{array}$ & $\begin{array}{l}3-y \\
\text { OS } \\
(\%)\end{array}$ & $\begin{array}{l}4-y \\
\text { OS } \\
(\%)\end{array}$ & $\begin{array}{l}5-y \\
\text { OS } \\
(\%)\end{array}$ \\
\hline $\begin{array}{c}\text { Tinguely/2020 } \\
{[132]}\end{array}$ & Retrospective & MWA & $\begin{array}{l}\text { Percutaneous } \\
\text { or surgical }\end{array}$ & 82 & $3 *$ & $\mathrm{n} / \mathrm{a}$ & 25.2 & 69.1 & $\mathrm{n} / \mathrm{a}$ & $\mathrm{n} / \mathrm{a}$ \\
\hline $\begin{array}{c}\text { Thai } \\
\text { Doan/2020 } \\
{[133]}\end{array}$ & Retrospective & RFA & Percutaneous & 61 & $\mathrm{n} / \mathrm{a}$ & 2.7 & 24 & 44.5 & $\mathrm{n} / \mathrm{a}$ & 38.2 \\
\hline $\begin{array}{c}\text { Cornelis / } 2020 \\
{[70]}\end{array}$ & Retrospective & IRE & Percutaneous & 25 & $\mathrm{n} / \mathrm{a}$ & $\mathrm{n} / \mathrm{a}$ & 25 & 26.8 & $\mathrm{n} / \mathrm{a}$ & $\mathrm{n} / \mathrm{a}$ \\
\hline $\begin{array}{c}\text { Schicho/2019 } \\
\text { [62] }\end{array}$ & Retrospective & IRE & Percutaneous & 24 & 2 & 2 & 26.5 & 25 & $\mathrm{n} / \mathrm{a}$ & 8.3 \\
\hline $\begin{array}{c}\text { Ruers / } 2017 \\
{[38]}\end{array}$ & Prospective & $\begin{array}{l}\mathrm{RFA} \pm \\
\text { resection }\end{array}$ & $\begin{array}{l}\text { Percutaneous } \\
\text { or surgical }\end{array}$ & $60^{+}$ & $4^{*}$ & 4 & 116.4 & 56.9 & $\mathrm{n} / \mathrm{a}$ & 43.1 \\
\hline $\begin{array}{c}\text { Engstrand / } 2014 \\
{[134]}\end{array}$ & Retrospective & MWA & Surgical & 20 & 2.7 & 9 & 25 & $\mathrm{n} / \mathrm{a}$ & 41 & $\mathrm{n} / \mathrm{a}$ \\
\hline $\begin{array}{c}\text { Evrard/2012 } \\
{[135]}\end{array}$ & Prospective & $\begin{array}{l}\mathrm{RFA} \pm \\
\text { resection }\end{array}$ & Surgical & 52 & 1 & 5 & 34.8 & $\mathrm{n} / \mathrm{a}$ & $\mathrm{n} / \mathrm{a}$ & 43 \\
\hline$\underset{\text { [129] }}{\mathrm{Kim} / 2011}$ & Retrospective & RFA & $\begin{array}{l}\text { Percutaneous } \\
\text { or surgical }\end{array}$ & 177 & 2.1 & 1.6 & 41.2 & $\mathrm{n} / \mathrm{a}$ & $\mathrm{n} / \mathrm{a}$ & 51 \\
\hline $\begin{array}{c}\text { Van } \\
\text { Tilborg/2011 } \\
\text { [136] }\end{array}$ & Retrospective & RFA & $\begin{array}{l}\text { Percutaneous } \\
\text { or surgical }\end{array}$ & 100 & 2.4 & 1.9 & 29 & 77 & $\mathrm{n} / \mathrm{a}$ & 36 \\
\hline
\end{tabular}

Abbreviations-IRE: irreversible electroporation; MWA: microwave ablation; n/a: not available; OS: overall survival; RFA: radiofrequency ablation. *: Maximal diameter. ${ }^{\dagger}$ : combined modality arm (systemic treatment plus aggressive local treatment by radiofrequency ablation \pm resection).

For unresectable or unablatable CLM, neoadjuvant chemotherapy provides potential conversion to resectable or ablatable disease. Four-year survival of $45 \%$ has been reported by one study using RFA in a small group of 51 patients following neoadjuvant chemotherapy [137]. Nevertheless, neoadjuvant chemotherapy could result in the disappearance of liver metastases. A study of 325 CLM lesions identified by contrast-enhanced CT before neoadjuvant chemotherapy reported that only 183 lesions were identified after chemotherapy by CT, while 309 lesions were identified during intraoperative ultrasound [137]. The tumors that have disappeared on imaging can still be present upon pathological analysis, and are likely to recur on the follow-up imaging [138]. Therefore, complete radiological response is not correlated with complete pathological response, and further locoregional treatment is warranted. Furthermore, a recent meta-analysis reported that the evidence to support the routine use of neoadjuvant chemotherapy in repeat locoregional treatment is lacking, and a further randomized controlled study is under development [139]. Adjuvant chemotherapy could provide benefits for patients undergoing ablation compared to ablation alone. A study of 234 patients found improved median overall survival of 28 months versus 19 months for those who received adjuvant chemotherapy following RFA $(p=0.02)$ [140]. Another study of MWA reported a similar result, in which median overall survival was longer for patients with multiple lesions receiving adjuvant chemotherapy after ablation (46.7 vs. 25 months; $p=0.009$ ) [101]. Nevertheless, such findings have not been validated in a prospective fashion. 


\subsection{Patients with Post-Resection Recurrence}

Although repeat hepatectomy has been reported to be effective, not all of the patients are eligible for re-resection, due to limited liver reserve, unfavorable tumor location, and/or patient comorbidities. Ablation can be utilized as a salvage treatment for these patients, with recent series demonstrating outcomes similar to surgical resection $[45,47,141,142]$. Furthermore, ablation can be used as a "test-of-time" strategy for patients who had positive margins at liver resection, or for those recurring within 6 months of liver resection. It can offer additional local tumor control and prolong overall survival in a selected heavily pretreated population with limited therapeutic options [47]. A summary of studies evaluating liver ablation following hepatectomy is provided in Table 2. 
Table 2. Relevant studies on survival following ablation of recurrent colorectal liver metastases after hepatectomy within 10 years.

\begin{tabular}{|c|c|c|c|c|c|c|c|c|c|c|c|}
\hline Author/Year & Type of Study & $\begin{array}{c}\text { Number of } \\
\text { Patients/Lesions }\end{array}$ & $\begin{array}{c}\text { Approach of } \\
\text { Ablation }\end{array}$ & $\begin{array}{l}\text { Mean/Median } \\
\text { Tumor Size (cm) }\end{array}$ & $\begin{array}{l}\text { Mean/Median } \\
\text { Tumor Number }\end{array}$ & $\begin{array}{l}\text { Median } \\
\text { Follow-Up } \\
\text { Period in } \\
\text { Months }\end{array}$ & $\begin{array}{l}\text { Local Tumor } \\
\text { Progression } \\
\text { Rate (\%) }\end{array}$ & $\begin{array}{l}\text { Liver Limited } \\
\text { Recurrence (\%) }\end{array}$ & $\begin{array}{l}\text { Repeat Local } \\
\text { Treatment for } \\
\text { Liver Limited } \\
\text { Recurrence (\%) }\end{array}$ & $\begin{array}{l}3-y \\
\text { OS } \\
(\%)\end{array}$ & $\begin{array}{l}5-y \\
\text { OS } \\
\text { (\%) }\end{array}$ \\
\hline Fan/2020 [143] & Retrospective & $144 / 258$ & $\begin{array}{c}\text { Percutaneous } \\
\text { RFA }\end{array}$ & 2.6 & 5.1 & 28.6 & 7 & $79.2 *$ & $\mathrm{n} / \mathrm{a}$ & $\mathrm{n} / \mathrm{a}$ & 27.1 \\
\hline$\underset{\text { [43] }}{\text { Zimmermann } / 2020}$ & Retrospective & $23 / 29$ & $\begin{array}{c}\text { Percutaneous } \\
\text { RFA }\end{array}$ & $\mathrm{n} / \mathrm{a}$ & $\mathrm{n} / \mathrm{a}$ & 26 & $\mathrm{n} / \mathrm{a}$ & 74 & $\mathrm{n} / \mathrm{a}$ & 57 & 24 \\
\hline $\begin{array}{c}\text { Schullian/2020 } \\
{[44]}\end{array}$ & Retrospective & $64 / 217$ & $\begin{array}{c}\text { Percutaneous } \\
\text { RFA } \$\end{array}$ & 2.7 & 2 & 21 & 11.5 & $48.4^{*}$ & 48.4 & 46.2 & 34.8 \\
\hline Mao/2019 [144] & Retrospective & $61 / 114$ & $\begin{array}{c}\text { Percutaneous } \\
\text { RFA }^{\#}\end{array}$ & 2.7 & 2 & 28.9 & 16.7 & 54.1 & 52 & $\mathrm{n} / \mathrm{a}$ & 33 \\
\hline Odisio/2018 [115] & Retrospective & $49 / 59$ & $\begin{array}{c}\text { Percutaneous } \\
\text { RFA, MWA, } \\
\text { and } \\
\text { Cryoablation }\end{array}$ & $\mathrm{n} / \mathrm{a}$ & $\mathrm{n} / \mathrm{a}$ & 28 & 5.1 & $\mathrm{n} / \mathrm{a}$ & $\mathrm{n} / \mathrm{a}$ & 78 & $\mathrm{n} / \mathrm{a}$ \\
\hline Dupré/2017 [45] & Retrospective & $33 / \mathrm{n} / \mathrm{a}$ & $\begin{array}{l}\text { Open or } \\
\text { percutaneous } \\
\text { RFA, MWA, } \\
\text { and IRE }\end{array}$ & 2 & 2 & 36.2 & $\mathrm{n} / \mathrm{a}$ & 54.5 & 88.9 & 30.4 & $\mathrm{n} / \mathrm{a}$ \\
\hline $\begin{array}{c}\text { Sofocleous / } 2011 \\
{[47]}\end{array}$ & Retrospective & $56 / 71$ & $\begin{array}{c}\text { Percutaneous } \\
\text { RFA }\end{array}$ & 1.9 & 1.3 & 22 & 50.7 & $\mathrm{n} / \mathrm{a}$ & 47.2 & 41 & $\mathrm{n} / \mathrm{a}$ \\
\hline
\end{tabular}

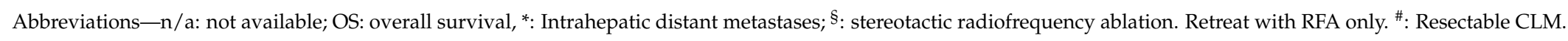




\subsection{Ablation in Combination with Surgical Resection}

Patients with extensive distribution of CLMs pose a challenge for curative-intent local therapies. Liver resection combined with ablation has been applied with the goal of achieving cure and preserving the future liver remnant in these patients $[39,42,145]$ (Table 3).

Table 3. Relevant studies published in the last 10 years on ablation + surgery versus surgery alone for colorectal liver metastases.

\begin{tabular}{|c|c|c|c|c|c|c|c|c|c|c|c|c|}
\hline Author/Year & $\begin{array}{l}\text { Type of } \\
\text { Study }\end{array}$ & Modality & $\begin{array}{c}\text { Number } \\
\text { of } \\
\text { Patients }\end{array}$ & $\begin{array}{c}\text { Mean/Median } \\
\text { Tumor } \\
\text { Size }(\mathbf{c m})\end{array}$ & $\begin{array}{c}\text { Mean/Median } \\
\text { Tumor } \\
\text { Number }\end{array}$ & $\begin{array}{l}\text { Median } \\
\text { Follow- } \\
\text { Up Period } \\
\text { (Months) }\end{array}$ & $\begin{array}{c}\text { Liver } \\
\text { Limited } \\
\text { Recurrence } \\
\text { Rate (\%) }\end{array}$ & $\begin{array}{c}\text { Repeat } \\
\text { Local } \\
\text { Treatment } \\
\text { for Liver } \\
\text { Limited } \\
\text { Recurrence } \\
(\%)\end{array}$ & $\begin{array}{l}3-y \\
\text { DFS } \\
(\%)\end{array}$ & $\begin{array}{l}5-y \\
\text { DFS } \\
(\%)\end{array}$ & $\begin{array}{l}3-y \\
\text { OS } \\
(\%)\end{array}$ & $\begin{array}{l}5-y \\
\text { OS } \\
(\%)\end{array}$ \\
\hline \multirow[t]{2}{*}{$\begin{array}{c}\text { van } \\
\text { Amerongen/ } \\
2019 \text { [146] }\end{array}$} & \multirow[t]{2}{*}{ Retrospective } & $\begin{array}{l}\text { RFA + } \\
\text { resection }\end{array}$ & 18 & 2.7 & 3 & 28 & $\mathrm{n} / \mathrm{a}$ & $\mathrm{n} / \mathrm{a}$ & 0 & $\mathrm{n} / \mathrm{a}$ & 43 & $\mathrm{n} / \mathrm{a}$ \\
\hline & & Resection & 63 & 3.2 & 1 & 28 & $\mathrm{n} / \mathrm{a}$ & $\mathrm{n} / \mathrm{a}$ & 16 & $\mathrm{n} / \mathrm{a}$ & 72 & $\mathrm{n} / \mathrm{a}$ \\
\hline \multirow{2}{*}{$\underset{[147]}{\operatorname{Mizuno} / 2018^{\dagger}}$} & \multirow[t]{2}{*}{ Retrospective } & $1 S \pm R F A$ & 101 & 4 & 5 & 39 & $\mathrm{n} / \mathrm{a}$ & $\mathrm{n} / \mathrm{a}$ & $\mathrm{n} / \mathrm{a}$ & $\mathrm{n} / \mathrm{a}$ & $\mathrm{n} / \mathrm{a}$ & 24 \\
\hline & & $2 S$ & 126 & 3.4 & 7 & 39 & $\mathrm{n} / \mathrm{a}$ & $\mathrm{n} / \mathrm{a}$ & $\mathrm{n} / \mathrm{a}$ & $\mathrm{n} / \mathrm{a}$ & $\mathrm{n} / \mathrm{a}$ & 35 \\
\hline \multirow{2}{*}{$\begin{array}{c}\text { Hof } / 2018 \\
{[148]}\end{array}$} & \multirow[t]{2}{*}{ Retrospective } & $\begin{array}{l}\text { RFA } \pm \\
\text { resection \# }\end{array}$ & 35 & 1.9 & $\mathrm{n} / \mathrm{a}$ & 36.1 & $\mathrm{n} / \mathrm{a}$ & $\mathrm{n} / \mathrm{a}$ & $\mathrm{n} / \mathrm{a}$ & 39.1 & $\mathrm{n} / \mathrm{a}$ & 49.2 \\
\hline & & Resection & 35 & 2.2 & $\mathrm{n} / \mathrm{a}$ & 36.1 & $\mathrm{n} / \mathrm{a}$ & $\mathrm{n} / \mathrm{a}$ & $\mathrm{n} / \mathrm{a}$ & 30.1 & $\mathrm{n} / \mathrm{a}$ & 56.3 \\
\hline \multirow[t]{2}{*}{$\begin{array}{c}\text { Imai / } 2017 \\
{[40]}\end{array}$} & \multirow[t]{2}{*}{ Retrospective } & $\begin{array}{l}\text { RFA + } \\
\text { resection }\end{array}$ & 31 & $\begin{array}{l}1.4 \text { (RFA) } 3 \\
\text { (resection) }\end{array}$ & $\begin{array}{l}2 \text { (RFA) } 5 \\
\text { (resection) }\end{array}$ & 35.6 & 58 & 59 & $\mathrm{n} / \mathrm{a}$ & 19 & $\mathrm{n} / \mathrm{a}$ & 57 \\
\hline & & Resection & 93 & 3.3 & 5 & 35.6 & 47 & 51.1 & $\mathrm{n} / \mathrm{a}$ & 17.9 & $\mathrm{n} / \mathrm{a}$ & 61 \\
\hline \multirow{2}{*}{$\begin{array}{c}\text { Sasaki/2016 } \\
\text { [149] }\end{array}$} & \multirow[t]{2}{*}{ Retrospective } & $\begin{array}{l}\text { RFA + } \\
\text { resection }\end{array}$ & 86 & 2.2 & 5 & 30.9 & $\mathrm{n} / \mathrm{a}$ & $\mathrm{n} / \mathrm{a}$ & $\mathrm{n} / \mathrm{a}$ & $\mathrm{n} / \mathrm{a}$ & 52.6 & 37.2 \\
\hline & & Resection & 399 & 2.5 & 2 & 30.9 & $\mathrm{n} / \mathrm{a}$ & $\mathrm{n} / \mathrm{a}$ & $\mathrm{n} / \mathrm{a}$ & $\mathrm{n} / \mathrm{a}$ & 73.8 & 58.7 \\
\hline \multirow{2}{*}{$\begin{array}{c}\text { Faitot/2014* } \\
{[145]}\end{array}$} & \multirow[t]{2}{*}{ Retrospective } & $1 S \pm R F A$ & 78 & $\mathrm{n} / \mathrm{a}$ & 9.7 & 47 & $\mathrm{n} / \mathrm{a}$ & 34 & 11 & 11 & 52 & 35 \\
\hline & & 2S & 78 & $\mathrm{n} / \mathrm{a}$ & 9.6 & 39 & $\mathrm{n} / \mathrm{a}$ & 28 & 12 & 8 & 49 & 29 \\
\hline \multirow{2}{*}{$\begin{array}{c}\text { Eltawil/2014 } \\
{[150]}\end{array}$} & \multirow[t]{2}{*}{ Retrospective } & $\begin{array}{c}\text { RFA + } \\
\text { resection }\end{array}$ & 24 & 3.3 & 3 & 36 & 50 & $\mathrm{n} / \mathrm{a}$ & 13 & $\mathrm{n} / \mathrm{a}$ & 66 & $\mathrm{n} / \mathrm{a}$ \\
\hline & & Resection & 150 & 2.7 & 1 & 35 & 25 & $\mathrm{n} / \mathrm{a}$ & 29 & $\mathrm{n} / \mathrm{a}$ & 61 & $\mathrm{n} / \mathrm{a}$ \\
\hline \multirow{2}{*}{$\underset{\text { [129] }}{\mathrm{Kim} / 2011}$} & \multirow[t]{2}{*}{ Retrospective } & $\begin{array}{l}\text { RFA + } \\
\text { resection }\end{array}$ & 27 & 2.1 & 3.1 & 21.6 & $\mathrm{n} / \mathrm{a}$ & $\mathrm{n} / \mathrm{a}$ & $\mathrm{n} / \mathrm{a}$ & 18.4 & $\mathrm{n} / \mathrm{a}$ & 22.9 \\
\hline & & Resection & 95 & 2.6 & 1.5 & 21.6 & $\mathrm{n} / \mathrm{a}$ & $\mathrm{n} / \mathrm{a}$ & $\mathrm{n} / \mathrm{a}$ & 16.2 & $\mathrm{n} / \mathrm{a}$ & 34.6 \\
\hline$\underset{[42]}{\text { Okuno } 2020}$ & Retrospective & $\begin{array}{l}\text { RFA/MWA } \\
\text { + resection }\end{array}$ & $\begin{array}{l}92^{a} \\
23^{b}\end{array}$ & $1^{1.1^{\mathrm{b}}}$ & 4 & 39.6 & $\mathrm{n} / \mathrm{a}$ & $\mathrm{n} / \mathrm{a}$ & $\mathrm{n} / \mathrm{a}$ & $\mathrm{n} / \mathrm{a}$ & $\mathrm{n} / \mathrm{a}$ & $52^{\mathrm{a}}$ \\
\hline
\end{tabular}

Abbreviations-DFS: disease-free survival; n/a: not available; OS: overall survival; 1S: one-stage hepatectomy; 2S: two-stage hepatectomy; *: In this study, patients were divided into one-stage and two-stage hepatectomy. The RFA was carried out on $92 \%$ of the one-stage group and $8 \%$ of the two-stage group; ${ }^{\dagger}$ : In this study, patients were divided into one-stage and two-stage hepatectomy. The RFA was carried out on $71 \%$ of the one-stage group and none of the two-stage group. ${ }^{\#}$ : In these 35 patients, 9 patients underwent RFA only; ${ }^{\text {a }}$ intraoperative ablation; ${ }^{\mathrm{b}}$ : planned incomplete resection and postoperative percutaneous completion ablation under cross-sectional imaging guidance for intentionally untreated tumors.

The combination of ablation with hepatectomy has been used to treat unresectable CLM. The benefits of adding ablation to hepatectomy include preserving the functional liver parenchyma and reducing the possibility of post-hepatectomy liver failure. A metaanalysis of seven studies from 2004 to 2017 compared hepatectomy to the combination of RFA and hepatectomy. The results showed that RFA in addition to hepatectomy for unresectable CLM resulted in comparable overall survival to hepatectomy alone. Moreover, the authors noted that among the eight studies published after 2012, seven showed similar OS when comparing ablation ( \pm partial resection) to partial resection alone, which might indicate recent ablative technique improvements [151]. Regarding the combination of MWA with hepatectomy, a study of 53 patients showed no significant difference in overall survival between MWA plus hepatectomy and hepatectomy alone (median OS: 28 vs. 39 months; $p=0.43$ ) [152]. A case series study reported a 5-year overall survival rate of $40.4 \%$ for MWA in addition to hepatectomy for unresectable CLM [39]. Conversely, a study compared two-stage hepatectomy to one-stage hepatectomy combined with RFA for bilobar CLM and found that two-stage hepatectomy improved the 5-year overall survival rate ( $35 \mathrm{vs.} 24 \% ; p=0.01$ ), with a lower incidence of postoperative hepatic insufficiency ( $6 \%$ vs. $28 \%, p<0.0001$ ) [147]. The authors suggested that surgeons may have inadvertently overablated the lesions in an attempt to reduce the local recurrence rate, but caused more unplanned damage to the future liver remnant. 
In a case-matched study comparing patients treated with hepatectomy combined with RFA and those treated with hepatectomy alone, there were no significant differences in 5 -year overall survival ( $57 \%$ vs. $61 \%, p=0.573)$ or disease-free survival $(19 \%$ vs. $17 \%$, $p=0.865$ ) [39]. Furthermore, a newly developed sequential treatment strategy-planned incomplete resection followed by postoperative percutaneous completion ablation for intentionally untreated lesions-has shown that this novel strategy may provide better local tumor control (5-year local tumor recurrence: 31.7 vs. $62.4 \%$; $p=0.03$ ) and lower complication rates when compared with intraoperative ablation, while showing no significant differences in 5-year overall survival (53.2 vs. $41.8 \% ; p=0.407$ ) [42].

\section{Conclusions and Future Perspective}

The role of ablation in the management of CLM has significantly evolved in recent years. Ablation is a well-recognized local treatment option that can provide great local tumor control for small CLMs where adequate minimal ablation margins can be achieved. When combined with systemic chemotherapy, ablation can provide survival benefits for patients with unresectable CLM when compared to chemotherapy alone. Ablation also allows safe, cost-effective longitudinal sequential locoregional therapy with curative intent for recurrent CLM, which is common after initial CLM resection. Further understanding of the impact of tumor biology, the use of advanced imaging guidance for procedure planning and assessment, and the expected results of ongoing clinical trials will help to tailor its application as a local cure for patients with CLM.

Author Contributions: Writing-review and editing, Y.-M.L.; writing-review, I.P. and K.K.B.; supervision, B.C.O. All authors have read and agreed to the published version of the manuscript.

Funding: This research was funded in part by the NIH 1R01CA235564 grant.

Acknowledgments: This manuscript was supported in part by the Image-Guided Cancer Therapy Research Program, the University of Texas, MD Anderson Cancer Center.

Conflicts of Interest: The authors declare no conflict of interest.

\section{References}

1. Rawla, P.; Sunkara, T.; Barsouk, A. Epidemiology of colorectal cancer: Incidence, mortality, survival, and risk factors. Prz. Gastroenterol. 2019, 14, 89-103. [CrossRef]

2. Engstrand, J.; Nilsson, H.; Strömberg, C.; Jonas, E.; Freedman, J. Colorectal cancer liver metastases-A population-based study on incidence, management and survival. BMC Cancer 2018, 18, 78. [CrossRef] [PubMed]

3. Choti, M.A.; Sitzmann, J.V.; Tiburi, M.F.; Sumetchotimetha, W.; Rangsin, R.; Schulick, R.D.; Lillemoe, K.D.; Yeo, C.J.; Cameron, J.L. Trends in Long-Term Survival Following Liver Resection for Hepatic Colorectal Metastases. Ann. Surg. 2002, 235, 759-766. [CrossRef]

4. Adam, R.; Delvart, V.; Pascal, G.; Valeanu, A.; Castaing, D.; Azoulay, D.; Giacchetti, S.; Paule, B.; Kunstlinger, F.; Ghémard, O.; et al. Rescue Surgery for Unresectable Colorectal Liver Metastases Downstaged by Chemotherapy: A model to predict long-term survival. Ann. Surg. 2004, 240, 644-658. [CrossRef]

5. Otto, G.; Düber, C.; Hoppe-Lotichius, M.; König, J.; Heise, M.; Pitton, M.B. Radiofrequency Ablation as First-Line Treatment in Patients With Early Colorectal Liver Metastases Amenable to Surgery. Ann. Surg. 2010, 251, 796-803. [CrossRef]

6. Oshowo, A.; Gillams, A.; Harrison, E.; Lees, W.R.; Taylor, I. Comparison of resection and radiofrequency ablation for treatment of solitary colorectal liver metastases. Br. J. Surg. 2003, 90, 1240-1243. [CrossRef]

7. Hammill, C.W.; Billingsley, K.G.; Cassera, M.A.; Wolf, R.F.; Ujiki, M.B.; Hansen, P.D. Outcome After Laparoscopic Radiofrequency Ablation of Technically Resectable Colorectal Liver Metastases. Ann. Surg. Oncol. 2011, 18, 1947-1954. [CrossRef]

8. Solbiati, L.; Ahmed, M.; Cova, L.; Ierace, T.; Brioschi, M.; Goldberg, S.N. Small Liver Colorectal Metastases Treated with Percutaneous Radiofrequency Ablation: Local Response Rate and Long-term Survival with Up to 10-year Follow-up. Radiology 2012, 265, 958-968. [CrossRef]

9. Puijk, R.S.; Ruarus, A.H.; Vroomen, L.; Van Tilborg, A.; Scheffer, H.J.; Nielsen, K.; De Jong, M.C.; De Vries, J.J.J.; Zonderhuis, B.M.; Eker, H.H.; et al. Colorectal liver metastases: Surgery versus thermal ablation (COLLISION)—A phase III single-blind prospective randomized controlled trial. BMC Cancer 2018, 18, 821. [CrossRef]

10. Yamazaki, K.; Nagase, M.; Tamagawa, H.; Ueda, S.; Tamura, T.; Murata, K.; Nakajima, T.E.; Baba, E.; Tsuda, M.; Moriwaki, T.; et al. Randomized phase III study of bevacizumab plus FOLFIRI and bevacizumab plus mFOLFOX6 as first-line treatment for patients with metastatic colorectal cancer (WJOG4407G). Ann. Oncol. 2016, 27, 1539-1546. [CrossRef] [PubMed] 
11. Simkens, L.H.; van Tinteren, H.; May, A.; ten Tije, A.J.; Creemers, G.J.; Loosveld, O.J.; de Jongh, F.; Erdkamp, F.L.G.; Erjavec, Z.; van der Torren, A.M.; et al. Maintenance treatment with capecitabine and bevacizumab in metastatic colorectal cancer (CAIRO3): A phase 3 randomised controlled trial of the Dutch Colorectal Cancer Group. Lancet 2015, 385, 1843-1852. [CrossRef]

12. Heinemann, V.; von Weikersthal, L.F.; Decker, T.; Kiani, A.; Vehling-Kaiser, U.; Al-Batran, S.-E.; Heintges, T.; Lerchenmüller, C.; Kahl, C.; Seipelt, G.; et al. FOLFIRI plus cetuximab versus FOLFIRI plus bevacizumab as first-line treatment for patients with metastatic colorectal cancer (FIRE-3): A randomised, open-label, phase 3 trial. Lancet Oncol. 2014, 15, 1065-1075. [CrossRef]

13. Cremolini, C.; Loupakis, F.; Antoniotti, C.; Lupi, C.; Sensi, E.; Lonardi, S.; Mezi, S.; Tomasello, G.; Ronzoni, M.; Zaniboni, A.; et al. FOLFOXIRI plus bevacizumab versus FOLFIRI plus bevacizumab as first-line treatment of patients with metastatic colorectal cancer: Updated overall survival and molecular subgroup analyses of the open-label, phase 3 TRIBE study. Lancet Oncol. 2015, 16, 1306-1315. [CrossRef]

14. Gillams, A.; Goldberg, N.; Ahmed, M.; Bale, R.; Breen, D.; Callstrom, M.; Chen, M.H.; Choi, B.I.; De Baere, T.; Dupuy, D.; et al. Thermal ablation of colorectal liver metastases: A position paper by an international panel of ablation experts, the interventional oncology sans frontières meeting 2013. Eur. Radiol. 2015, 25, 3438-3454. [CrossRef]

15. Shady, W.; Petre, E.N.; Gonen, M.; Erinjeri, J.P.; Brown, K.T.; Covey, A.M.; Alago, W.; Durack, J.; Maybody, M.; Brody, L.A.; et al. Percutaneous Radiofrequency Ablation of Colorectal Cancer Liver Metastases: Factors Affecting Outcomes-A 10-year Experience at a Single Center. Radiology 2016, 278, 601-611. [CrossRef] [PubMed]

16. Mulier, S.; Ni, Y.; Jamart, J.; Ruers, T.; Marchal, G.; Michel, L. Local Recurrence After Hepatic Radiofrequency Coagulation: Multivariate meta-analysis and review of contributing factors. Ann. Surg. 2005, 242, 158-171. [CrossRef] [PubMed]

17. Ayav, A.; Germain, A.; Marchal, F.; Tierris, I.; Laurent, V.; Bazin, C.; Yuan, Y.; Robert, L.; Brunaud, L.; Bresler, L. Radiofrequency ablation of unresectable liver tumors: Factors associated with incomplete ablation or local recurrence. Am. J. Surg. 2010, 200, 435-439. [CrossRef]

18. Schullian, P.; Johnston, E.W.; Putzer, D.; Eberle, G.; Laimer, G.; Bale, R. Safety and efficacy of stereotactic radiofrequency ablation for very large $(\geq 8 \mathrm{~cm})$ primary and metastatic liver tumors. Sci. Rep. 2020, 10, 1-11. [CrossRef] [PubMed]

19. Nielsen, K.; Van Tilborg, A.A.; Meijerink, M.R.; Macintosh, M.O.; Zonderhuis, B.M.; De Lange, E.S.M.; Comans, E.F.I.; Meijer, S.; Tol, M.P.V.D. Incidence and Treatment of Local Site Recurrences Following RFA of Colorectal Liver Metastases. World J. Surg. 2013, 37, 1340-1347. [CrossRef]

20. Gillams, A.R.; Lees, W.R. Five-year survival in 309 patients with colorectal liver metastases treated with radiofrequency ablation. Eur. Radiol. 2009, 19, 1206-1213. [CrossRef]

21. Shady, W.; Petre, E.N.; Do, K.G.; Gonen, M.; Yarmohammadi, H.; Brown, K.T.; Kemeny, N.E.; D'Angelica, M.; Kingham, P.T.; Solomon, S.B.; et al. Percutaneous Microwave versus Radiofrequency Ablation of Colorectal Liver Metastases: Ablation with Clear Margins (A0) Provides the Best Local Tumor Control. J. Vasc. Interv. Radiol. 2018, 29, 268-275.e1. [CrossRef]

22. Livraghi, T.; Solbiati, L.; Meloni, F.; Ierace, T.; Goldberg, S.N.; Gazelle, G.S. Percutaneous radiofrequency ablation of liver metastases in potential candidates for resection: The "test-of-time approach". Cancer 2003, 97, 3027-3035. [CrossRef] [PubMed]

23. Meijerink, M.R.; Puijk, R.S.; van den Tol, P.M. Collision Trial Seeks to Answer Time-Honored Question: "Thermal Ablation or Surgery for Colorectal Liver Metastases?". Cardiovasc. Interv. Radiol. 2019, 42, 1059-1061. [CrossRef] [PubMed]

24. Marchal, F.; Leroux, A.; Verhaeghe, J.; Elias, D.; Rauch, P.; Stinès, J.; Guillemin, F.; Villemot, J. Biliary Lesions during Radiofrequency Ablation in Liver. Study on the pig. Eur. Surg. Res. 2004, 36, 88-94. [CrossRef] [PubMed]

25. Kurilova, I.; Bendet, A.; Petre, E.N.; Boas, F.E.; Kaye, E.; Gonen, M.; Covey, A.; Brody, L.A.; Brown, K.T.; Kemeny, N.E.; et al. Factors Associated With Local Tumor Control and Complications After Thermal Ablation of Colorectal Cancer Liver Metastases: A 15-year Retrospective Cohort Study. Clin. Color. Cancer 2021, 20, e82-e95. [CrossRef]

26. Yu, N.C.; Raman, S.S.; Kim, Y.J.; Lassman, C.; Chang, X.; Lu, D.S. Microwave Liver Ablation: Influence of Hepatic Vein Size on Heat-sink Effect in a Porcine Model. J. Vasc. Interv. Radiol. 2008, 19, 1087-1092. [CrossRef]

27. Pillai, K.; Akhter, J.; Chua, T.C.; Shehata, M.; Alzahrani, N.; Al-Alem, I.; Morris, D.L. Heat Sink Effect on Tumor Ablation Characteristics as Observed in Monopolar Radiofrequency, Bipolar Radiofrequency, and Microwave, Using Ex Vivo Calf Liver Model. Medicine 2015, 94, e580. [CrossRef]

28. Rhaiem, R.; Kianmanesh, R.; Minon, M.; Tashkandi, A.; Aghaei, A.; LeDoux, G.; Hoeffel, C.; Bouche, O.; Sommacale, D.; Piardi, T. Microwave Thermoablation of Colorectal Liver Metastases Close to Large Hepatic Vessels Under Pringle Maneuver Minimizes the "Heat Sink Effect". World J. Surg. 2020, 44, 1595-1603. [CrossRef]

29. Chiang, J.; Cristescu, M.; Lee, M.H.; Moreland, A.; Hinshaw, J.L.; Lee, F.T.; Brace, C. Effects of Microwave Ablation on Arterial and Venous Vasculature after Treatment of Hepatocellular Carcinoma. Radiology 2016, 281, 617-624. [CrossRef]

30. Silk, M.T.; Wimmer, T.; Lee, K.S.; Srimathveeravalli, G.; Brown, K.T.; Kingham, P.T.; Fong, Y.; Durack, J.; Sofocleous, C.T.; Solomon, S.B. Percutaneous Ablation of Peribiliary Tumors with Irreversible Electroporation. J. Vasc. Interv. Radiol. 2014, 25, 112-118. [CrossRef]

31. Dollinger, M.; Zeman, F.; Niessen, C.; Lang, S.A.; Beyer, L.P.; Müller, M.; Stroszczynski, C.; Wiggermann, P. Bile Duct Injury after Irreversible Electroporation of Hepatic Malignancies: Evaluation of MR Imaging Findings and Laboratory Values. J. Vasc. Interv. Radiol. 2016, 27, 96-103. [CrossRef] [PubMed]

32. Izaaryene, J.; Drai, M.; Deniel, C.; Bridge, P.; Rico, G.; Daidj, N.; Gilabert, M.; Ewald, J.; Turrini, O.; Piana, G. Computed tomography-guided microwave ablation of perivascular liver metastases from colorectal cancer: A study of the ablation zone, feasibility, and safety. Int. J. Hyperth. 2021, 38, 887-899. [CrossRef] [PubMed] 
33. Hamada, A.; Yamakado, K.; Nakatsuka, A.; Uraki, J.; Kashima, M.; Takaki, H.; Yamanaka, T.; Inoue, Y.; Kusunoki, M.; Takeda, K. Radiofrequency ablation for colorectal liver metastases: Prognostic factors in non-surgical candidates. Jpn. J. Radiol. 2012, 30, 567-574. [CrossRef]

34. Petre, E.N.; Jia, X.; Thornton, R.H.; Sofocleous, C.T.; Alago, W.; Kemeny, N.E.; Solomon, S.B. Treatment of Pulmonary Colorectal Metastases by Radiofrequency Ablation. Clin. Color. Cancer 2013, 12, 37-44. [CrossRef]

35. Sofocleous, C.T.; Nascimento, R.G.; Petrovic, L.M.; Klimstra, D.S.; Gonen, M.; Brown, K.T.; Brody, L.A.; Covey, A.M.; Thornton, R.H.; Fong, Y.; et al. Histopathologic and Immunohistochemical Features of Tissue Adherent to Multitined Electrodes after RF Ablation of Liver Malignancies Can Help Predict Local Tumor Progression: Initial Results. Radiology 2008, 249, 364-374. [CrossRef]

36. Solbiati, L.; Livraghi, T.; Goldberg, S.N.; Ierace, T.; Meloni, F.; Dellanoce, M.; Cova, L.; Halpern, E.F.; Gazelle, G.S. Percutaneous Radio-frequency Ablation of Hepatic Metastases from Colorectal Cancer: Long-term Results in 117 Patients. Radiology 2001, 221, 159-166. [CrossRef]

37. Han, K.; Kim, J.H.; Yang, S.G.; Park, S.H.; Choi, H.K.; Chun, S.Y.; Kim, P.N.; Park, J.; Lee, M. A Single-Center Retrospective Analysis of Periprocedural Variables Affecting Local Tumor Progression after Radiofrequency Ablation of Colorectal Cancer Liver Metastases. Radiology 2021, 298, 212-218. [CrossRef]

38. Ruers, T.; Van Coevorden, F.; Punt, C.J.A.; Pierie, J.-P.E.N.; Borel-Rinkes, I.; Ledermann, J.A.; Poston, G.; Bechstein, W.; Lentz, M.-A.; Mauer, M.; et al. Local Treatment of Unresectable Colorectal Liver Metastases: Results of a Randomized Phase II Trial. J. Natl. Cancer Inst. 2017, 109, djx015. [CrossRef]

39. Philips, P.; Groeschl, R.T.; Hanna, E.M.; Swan, R.Z.; Turaga, K.; Martinie, J.B.; Iannitti, D.A.; Schmidt, C.; Gamblin, T.C.L.; Martin, R.C.G. Single-stage resection and microwave ablation for bilobar colorectal liver metastases. Br. J. Surg. 2016, 103, 1048-1054. [CrossRef]

40. Imai, K.; Allard, M.; Castro-Benitez, C.; Vibert, E.; Cunha, A.S.; Cherqui, D.; Castaing, D.; Baba, H.; Adam, R. Long-term outcomes of radiofrequency ablation combined with hepatectomy compared with hepatectomy alone for colorectal liver metastases. $\mathrm{Br}$. $\mathrm{J}$. Surg. 2017, 104, 570-579. [CrossRef]

41. Kawaguchi, Y.; Lillemoe, H.A.; Vauthey, J. Dealing with an insufficient future liver remnant: Portal vein embolization and two-stage hepatectomy. J. Surg. Oncol. 2019, 119, 594-603. [CrossRef]

42. Okuno, M.; Kawaguchi, Y.; De Bellis, M.; Vega, E.A.; Huang, S.Y.; Ahrar, K.; Gupta, S.; Vauthey, J.-N.; Odisio, B.C. A new sequential treatment strategy for multiple colorectal liver metastases: Planned incomplete resection and postoperative completion ablation for intentionally-untreated tumors under guidance of cross-sectional imaging. Eur. J. Surg. Oncol. 2021, 47, 311-316. [CrossRef]

43. Zimmermann, M.; Pedersoli, F.; Schulze-Hagen, M.; Lurje, G.; Isfort, P.; Kuhl, C.; Bruners, P. Salvage RFA in patients with intrahepatic recurrence after major hepatic surgery for colorectal cancer liver metastases: Mid-term outcome. Eur. Radiol. 2020, 30, 1221-1227. [CrossRef]

44. Schullian, P.; Johnston, E.W.; Putzer, D.; Laimer, G.; Waroschitz, G.; Braunwarth, E.; Amann, A.; Maglione, M.; Bale, R. Stereotactic radiofrequency ablation (SRFA) for recurrent colorectal liver metastases after hepatic resection. Eur. J. Surg. Oncol. 2021, 47, 866-873. [CrossRef]

45. Dupré, A.; Jones, R.P.; Diaz-Nieto, R.; Fenwick, S.W.; Poston, G.J.; Malik, H.Z. Curative-intent treatment of recurrent colorectal liver metastases: A comparison between ablation and resection. Eur. J. Surg. Oncol. 2017, 43, 1901-1907. [CrossRef]

46. Dupré, A.; Rehman, A.; Jones, R.P.; Parker, A.; Diaz-Nieto, R.; Fenwick, S.W.; Poston, G.J.; Malik, H.Z. Validation of clinical prognostic scores for patients treated with curative-intent for recurrent colorectal liver metastases. J. Surg. Oncol. 2018, 117, 1330-1336. [CrossRef]

47. Sofocleous, C.T.; Petre, E.N.; Gonen, M.; Brown, K.T.; Solomon, S.B.; Covey, A.M.; Alago, W.; Brody, L.A.; Thornton, R.H.; D'Angelica, M.; et al. CT-guided Radiofrequency Ablation as a Salvage Treatment of Colorectal Cancer Hepatic Metastases Developing after Hepatectomy. J. Vasc. Interv. Radiol. 2011, 22, 755-761. [CrossRef]

48. Rhim, H.; Lim, H.K.; Kim, Y.-S.; Choi, D.; Lee, W.J. Radiofrequency ablation of hepatic tumors: Lessons learned from 3000 procedures. J. Gastroenterol. Hepatol. 2008, 23, 1492-1500. [CrossRef]

49. Fan, H.; Wang, X.; Qu, J.; Lu, W.; Pang, Z.; Shao, T.; Xia, J.; Wang, H.; Li, G.; Zhang, Y.; et al. Periprocedural risk factors for incomplete radiofrequency ablation of liver metastases from colorectal cancer: A single-center retrospective analysis. Int. J. Hyperth. 2021, 38, 985-994. [CrossRef]

50. Van Tilborg, A.A.; Scheffer, H.J.; De Jong, M.C.; Vroomen, L.G.; Nielsen, K.; Van Kuijk, C.; van den Tol, P.M.P.; Meijerink, M. MWA Versus RFA for Perivascular and Peribiliary CRLM: A Retrospective Patient- and Lesion-Based Analysis of Two Historical Cohorts. Cardiovasc. Interv. Radiol. 2016, 39, 1438-1446. [CrossRef]

51. Ierardi, A.M.; Floridi, C.; Fontana, F.; Chini, C.; Giorlando, F.; Piacentino, F.; Brunese, L.; Pinotti, G.; Bacuzzi, A.; Carrafiello, G. Microwave ablation of liver metastases to overcome the limitations of radiofrequency ablation. Radiol. Med. 2013, 118, 949-961. [CrossRef] [PubMed]

52. Liu, Y.; Li, S.; Wan, X.; Li, Y.; Li, B.; Zhang, Y.; Yuan, Y.; Zheng, Y. Efficacy and safety of thermal ablation in patients with liver metastases. Eur. J. Gastroenterol. Hepatol. 2013, 25, 442-446. [CrossRef] [PubMed] 
53. Correa, J.C.; Fong, Y.; Gonen, M.; D’Angelica, M.I.; Allen, P.J.; DeMatteo, R.P.; Jarnagin, W.R.; Kingham, T.P. A Retrospective Comparison of Microwave Ablation vs. Radiofrequency Ablation for Colorectal Cancer Hepatic Metastases. Ann. Surg. Oncol. 2014, 21, 4278-4283. [CrossRef]

54. Takahashi, H.; Kahramangil, B.; Kose, E.; Berber, E. A comparison of microwave thermosphere versus radiofrequency thermal ablation in the treatment of colorectal liver metastases. HPB 2018, 20, 1157-1162. [CrossRef]

55. Huo, Y.R.; Eslick, G.D. Microwave Ablation Compared to Radiofrequency Ablation for Hepatic Lesions: A Meta-Analysis. J. Vasc. Interv. Radiol. 2015, 26, 1139-1146.e2. [CrossRef]

56. Seifert, J.K.; Junginger, T. Cryotherapy for Liver Tumors: Current Status, Perspectives, Clinical Results, and Review of Literature. Technol. Cancer Res. Treat. 2004, 3, 151-163. [CrossRef]

57. Littrup, P.J.; Aoun, H.D.; Adam, B.; Krycia, M.; Prus, M.; Shields, A. Percutaneous cryoablation of hepatic tumors: Long-term experience of a large U.S. series. Abdom. Radiol. 2016, 41, 767-780. [CrossRef] [PubMed]

58. Lee, E.W.; Wong, D.; Prikhodko, S.V.; Perez, A.; Tran, C.; Loh, C.T.; Kee, S.T. Electron Microscopic Demonstration and Evaluation of Irreversible Electroporation-Induced Nanopores on Hepatocyte Membranes. J. Vasc. Interv. Radiol. 2012, 23, 107-113. [CrossRef]

59. Nielsen, K.; Scheffer, H.J.; Vieveen, J.M.; van Tilborg, A.A.; Meijer, S.; van Kuijk, C.; van den Tol, M.P.; Meijerink, M.; Bouwman, R.A. Anaesthetic management during open and percutaneous irreversible electroporation. Br. J. Anaesth. 2014, 113, 985-992. [CrossRef]

60. Thomson, K.R.; Cheung, W.; Ellis, S.J.; Federman, D.; Kavnoudias, H.; Loader-Oliver, D.; Roberts, S.; Evans, P.; Ball, C.M.; Haydon, A. Investigation of the Safety of Irreversible Electroporation in Humans. J. Vasc. Interv. Radiol. 2011, 22, 611-621. [CrossRef]

61. Cannon, R.; Ellis, S.; Hayes, D.; Narayanan, G.; Martin, R.C., 2nd. Safety and early efficacy of irreversible electroporation for hepatic tumors in proximity to vital structures. J. Surg. Oncol. 2013, 107, 544-549. [CrossRef] [PubMed]

62. Schicho, A.; Niessen, C.; Haimerl, M.; Wiesinger, I.; Stroszczynski, C.; Beyer, L.P.; Wiggermann, P. Long-term survival after percutaneous irreversible electroporation of inoperable colorectal liver metastases. Cancer Manag. Res. 2019, 11, 317-322. [CrossRef] [PubMed]

63. Stillström, D.; Beermann, M.; Engstrand, J.; Freedman, J.; Nilsson, H. Initial experience with irreversible electroporation of liver tumours. Eur. J. Radiol. Open 2019, 6, 62-67. [CrossRef]

64. Distelmaier, M.; Barabasch, A.; Heil, P.; Kraemer, N.A.; Isfort, P.; Keil, S.; Kuhl, C.; Bruners, P. Midterm Safety and Efficacy of Irreversible Electroporation of Malignant Liver Tumors Located Close to Major Portal or Hepatic Veins. Radiology 2017, 285, 1023-1031. [CrossRef] [PubMed]

65. Ben-David, E.; Appelbaum, L.; Sosna, J.; Nissenbaum, I.; Goldberg, S.N. Characterization of Irreversible Electroporation Ablation in In Vivo Porcine Liver. Am. J. Roentgenol. 2012, 198, W62-W68. [CrossRef]

66. Hoffmann, R.; Rempp, H.; Erhard, L.; Blumenstock, G.; Pereira, P.L.; Claussen, C.D.; Clasen, S. Comparison of Four Microwave Ablation Devices: An Experimental Study in ex Vivo Bovine Liver. Radiology 2013, 268, 89-97. [CrossRef]

67. Beyer, L.P.; Pregler, B.; Nießen, C.; Schicho, A.; Haimerl, M.; Jung, E.M.; Stroszczynski, C.; Wiggermann, P. Stereotacticallynavigated percutaneous Irreversible Electroporation (IRE) compared to conventional IRE: A prospective trial. PeerJ 2016, 4, e2277. [CrossRef]

68. Gonzalez-Beicos, A.; Venkat, S.; Songrug, T.; Poveda, J.; Garcia-Buitrago, M.; Mohan, P.P.; Narayanan, G. Irreversible Electroporation of Hepatic and Pancreatic Malignancies: Radiologic-Pathologic Correlation. Tech. Vasc. Interv. Radiol. 2015, 18, 176-182. [CrossRef] [PubMed]

69. Felker, E.R.; Dregely, I.; Chung, D.J.; Sung, K.; Osuagwu, F.C.; Lassman, C.; Sayre, J.; Wu, H.; Lu, D.S. Irreversible Electroporation: Defining the MRI Appearance of the Ablation Zone With Histopathologic Correlation in a Porcine Liver Model. Am. J. Roentgenol. 2017, 208, 1141. [CrossRef]

70. Cornelis, F.H.; Cindrič, H.; Kos, B.; Fujimori, M.; Petre, E.N.; Miklavčič, D.; Solomon, S.B.; Srimathveeravalli, G. Peri-tumoral Metallic Implants Reduce the Efficacy of Irreversible Electroporation for the Ablation of Colorectal Liver Metastases. Cardiovasc. Interv. Radiol. 2020, 43, 84-93. [CrossRef]

71. Hosein, P.J.; Echenique, A.; Loaiza-Bonilla, A.; Froud, T.; Barbery, K.; Lima, C.M.R.; Yrizarry, J.M.; Narayanan, G. Percutaneous Irreversible Electroporation for the Treatment of Colorectal Cancer Liver Metastases with a Proposal for a New Response Evaluation System. J. Vasc. Interv. Radiol. 2014, 25, 1233-1239.e2. [CrossRef]

72. Meijerink, M.R.; Ruarus, A.H.; Vroomen, L.; Puijk, R.S.; Geboers, B.; Nieuwenhuizen, S.; Bemd, B.A.T.V.D.; Nielsen, K.; de Vries, J.J.J.; van Lienden, K.P.; et al. Irreversible Electroporation to Treat Unresectable Colorectal Liver Metastases (COLDFIRE-2): A Phase II, Two-Center, Single-Arm Clinical Trial. Radiology 2021, 299, 470-480. [CrossRef]

73. Ahmed, M.; Solbiati, L.; Brace, C.L.; Breen, D.J.; Callstrom, M.R.; Charboneau, J.W.; Chen, M.-H.; Choi, B.I.; De Baère, T.; Dodd, G.D.; et al. Image-guided Tumor Ablation: Standardization of Terminology and Reporting Criteria-A 10-Year Update. Radiology 2014, 273, 241-260. [CrossRef]

74. Adams, R.B.; Aloia, T.A.; Loyer, E.; Pawlik, T.M.; Taouli, B.; Vauthey, J.N. Selection for hepatic resection of colorectal liver metastases: Expert consensus statement. HPB 2013, 15, 91-103. [CrossRef]

75. Moulton, C.-A.; Gu, C.-S.; Law, C.H.; Tandan, V.R.; Hart, R.; Quan, D.; Smith, R.J.F.; Jalink, D.W.; Husien, M.; Serrano, P.E.; et al. Effect of PET Before Liver Resection on Surgical Management for Colorectal Adenocarcinoma Metastases: A randomized clinical trial. JAMA 2014, 311, 1863-1869. [CrossRef] 
76. Oba, A.; Mise, Y.; Ito, H.; Hiratsuka, M.; Inoue, Y.; Ishizawa, T.; Arita, J.; Matsueda, K.; Takahashi, Y.; Saiura, A. Clinical implications of disappearing colorectal liver metastases have changed in the era of hepatocyte-specific MRI and contrast-enhanced intraoperative ultrasonography. HPB 2018, 20, 708-714. [CrossRef] [PubMed]

77. National Comprehensive Cancer Network. Colon Cancer (Version 2.2021). Available online: https://www.nccn.org/professionals/ physician_gls/pdf/colon.pdf (accessed on 1 April 2021).

78. Hoffmann, R.; Rempp, H.; Keßler, D.-E.; Weiß, J.; Pereira, P.L.; Nikolaou, K.; Clasen, S. MR-guided microwave ablation in hepatic tumours: Initial results in clinical routine. Eur. Radiol. 2017, 27, 1467-1476. [CrossRef] [PubMed]

79. Terraz, S.; Cernicanu, A.; Lepetit-Coiffé, M.; Viallon, M.; Salomir, R.; Mentha, G.; Becker, C.D. Radiofrequency ablation of small liver malignancies under magnetic resonance guidance: Progress in targeting and preliminary observations with temperature monitoring. Eur. Radiol. 2010, 20, 886-897. [CrossRef]

80. Francica, G.; Meloni, M.F.; Riccardi, L.; de Sio, I.; Terracciano, F.; Caturelli, E.; Iadevaia, M.D.; Amoruso, A.; Roselli, P.; Chiang, J.; et al. Ablation treatment of primary and secondary liver tumors under contrast-enhanced ultrasound guidance in field practice of interventional ultrasound centers. A multicenter study. Eur. J. Radiol. 2018, 105, 96-101. [CrossRef]

81. Bo, X.-W.; Xu, H.-X.; Guo, L.-H.; Sun, L.-P.; Li, X.-L.; Zhao, C.-K.; He, Y.-P.; Liu, B.-J.; Li, D.-D.; Zhang, K.; et al. Ablative safety margin depicted by fusion imaging with post-treatment contrast-enhanced ultrasound and pre-treatment CECT/CEMRI after radiofrequency ablation for liver cancers. Br. J. Radiol. 2017, 90, 20170063. [CrossRef] [PubMed]

82. Sahin, D.A.; Agcaoglu, O.; Chretien, C.; Siperstein, A.; Berber, E. The Utility of PET/CT in the Management of Patients With Colorectal Liver Metastases Undergoing Laparascopic Radiofrequency Thermal Ablation. Ann. Surg. Oncol. 2012, 19, 850-855. [CrossRef]

83. Cornelis, F.; Storchios, V.; Violari, E.; Sofocleous, C.T.; Schoder, H.; Durack, J.C.; Siegelbaum, R.H.; Maybody, M.; Humm, J.; Solomon, S.B. 18F-FDG PET/CT Is an Immediate Imaging Biomarker of Treatment Success After Liver Metastasis Ablation. J. Nucl. Med. 2016, 57, 1052-1057. [CrossRef]

84. Cornelis, F.H.; Petre, E.N.; Vakiani, E.; Klimstra, D.; Durack, J.C.; Gonen, M.; Osborne, J.; Solomon, S.B.; Sofocleous, C.T. Immediate Postablation18F-FDG Injection and Corresponding SUV Are Surrogate Biomarkers of Local Tumor Progression After Thermal Ablation of Colorectal Carcinoma Liver Metastases. J. Nucl. Med. 2018, 59, 1360-1365. [CrossRef]

85. Sainani, N.I.; Shyn, P.B.; Tatli, S.; Morrison, P.R.; Tuncali, K.; Silverman, S.G. PET/CT-guided Radiofrequency and Cryoablation: Is Tumor Fluorine-18 Fluorodeoxyglucose Activity Dissipated by Thermal Ablation? J. Vasc. Interv. Radiol. 2011, 22, 354-360. [CrossRef]

86. Ryan, E.R.; Sofocleous, C.T.; Schöder, H.; Carrasquillo, J.A.; Nehmeh, S.; Larson, S.; Thornton, R.; Siegelbaum, R.H.; Erinjeri, J.P.; Solomon, S.B. Split-Dose Technique for FDG PET/CT-guided Percutaneous Ablation: A Method to Facilitate Lesion Targeting and to Provide Immediate Assessment of Treatment Effectiveness. Radiology 2013, 268, 288-295. [CrossRef]

87. Shyn, P.B.; Casadaban, L.C.; Sainani, N.I.; Sadow, C.A.; Bunch, P.M.; Levesque, V.M.; Kim, C.K.; Gerbaudo, V.H.; Silverman, S.G. Intraprocedural Ablation Margin Assessment by Using Ammonia Perfusion PET during FDG PET/CT-guided Liver Tumor Ablation: A Pilot Study. Radiology 2018, 288, 138-145. [CrossRef]

88. Beermann, M.; Lindeberg, J.; Engstrand, J.; Galmén, K.; Karlgren, S.; Stillström, D.; Nilsson, H.; Harbut, P.; Freedman, J. 1000 consecutive ablation sessions in the era of computer assisted image guidance-Lessons learned. Eur. J. Radiol. Open 2019, 6, 1-8. [CrossRef]

89. Bale, R.; Widmann, G.; Schullian, P.; Haidu, M.; Pall, G.; Klaus, A.; Weiss, H.; Biebl, M.; Margreiter, R. Percutaneous stereotactic radiofrequency ablation of colorectal liver metastases. Eur. Radiol. 2012, 22, 930-937. [CrossRef] [PubMed]

90. Schullian, P.; Johnston, E.; Laimer, G.; Putzer, D.; Eberle, G.; Westerlund, P.; Henninger, B.; Bale, R. Thermal ablation of CT 'invisible' liver tumors using MRI fusion: A case control study. Int. J. Hyperth. 2020, 37, 564-572. [CrossRef] [PubMed]

91. Iwan, P.; Raluca-Maria, S.; Pascale, T.; Corina, K.-F.; Martin, M.; Daniel, C. Stereotactic Image-Guidance for Ablation of Malignant Liver Tumors. In Liver Pathology; IntechOpen: London, UK, 2021.

92. Morimoto, M.; Numata, K.; Kondo, M.; Nozaki, A.; Hamaguchi, S.; Takebayashi, S.; Tanaka, K. C-Arm Cone Beam CT for Hepatic Tumor Ablation Under Real-Time 3D Imaging. Am. J. Roentgenol. 2010, 194, W452-W454. [CrossRef] [PubMed]

93. Schullian, P.; Putzer, D.; Eberle, G.; Laimer, G.; Bale, R. Simultaneous Stereotactic Radiofrequency Ablation of Multiple ( $\geq 4$ ) Liver Tumors: Feasibility, Safety, and Efficacy. J. Vasc. Interv. Radiol. 2020, 31, 943-952. [CrossRef]

94. Maybody, M.; Stevenson, C.; Solomon, S.B. Overview of Navigation Systems in Image-Guided Interventions. Tech. Vasc. Interv. Radiol. 2013, 16, 136-143. [CrossRef]

95. Heerink, W.J.; Ruiter, S.; Pennings, J.P.; Lansdorp, B.; Vliegenthart, R.; Oudkerk, M.; De Jong, K.P. Robotic versus Freehand Needle Positioning in CT-guided Ablation of Liver Tumors: A Randomized Controlled Trial. Radiology 2019, 290, 826-832. [CrossRef] [PubMed]

96. Beyer, L.P.; Pregler, B.; Niessen, C.; Dollinger, M.; Graf, B.M.; Müller, M.; Schlitt, H.J.; Stroszczynski, C.; Wiggermann, P. Robotassisted microwave thermoablation of liver tumors: A single-center experience. Int. J. Comput. Assist. Radiol. Surg. 2016, 11, 253-259. [CrossRef] [PubMed]

97. Beyer, L.P.; Lürken, L.; Verloh, N.; Haimerl, M.; Michalik, K.; Schaible, J.; Stroszczynski, C.; Wiggermann, P. Stereotactically navigated percutaneous microwave ablation (MWA) compared to conventional MWA: A matched pair analysis. Int. J. Comput. Assist. Radiol. Surg. 2018, 13, 1991-1997. [CrossRef] 
98. Schaible, J.; Lürken, L.; Wiggermann, P.; Verloh, N.; Einspieler, I.; Zeman, F.; Schreyer, A.G.; Bale, R.; Stroszczynski, C.; Beyer, L. Primary efficacy of percutaneous microwave ablation of malignant liver tumors: Comparison of stereotactic and conventional manual guidance. Sci. Rep. 2020, 10, 8835. [CrossRef] [PubMed]

99. Abdalla, E.K.; Vauthey, J.-N.; Ellis, L.M.; Ellis, V.; Pollock, R.; Broglio, K.R.; Hess, K.; Curley, S.A. Recurrence and Outcomes Following Hepatic Resection, Radiofrequency Ablation, and Combined Resection/Ablation for Colorectal Liver Metastases. Ann. Surg. 2004, 239, 818-825. [CrossRef] [PubMed]

100. Kim, Y.-S.; Rhim, H.; Cho, O.K.; Koh, B.H.; Kim, Y. Intrahepatic recurrence after percutaneous radiofrequency ablation of hepatocellular carcinoma: Analysis of the pattern and risk factors. Eur. J. Radiol. 2006, 59, 432-441. [CrossRef] [PubMed]

101. Shi, Y.; Wang, Z.; Chi, J.; Shi, D.; Wang, T.; Cui, D.; Lin, Y.; Zhai, B. Long-term results of percutaneous microwave ablation for colorectal liver metastases. HPB 2020, 23, 37-45. [CrossRef] [PubMed]

102. Narayanan, G.; Bhatia, S.; Echenique, A.; Suthar, R.; Barbery, K.; Yrizarry, J. Vessel Patency Post Irreversible Electroporation. Cardiovasc. Interv. Radiol. 2014, 37, 1523-1529. [CrossRef]

103. Calandri, M.; Yamashita, S.; Gazzera, C.; Fonio, P.; Veltri, A.; Bustreo, S.; Sheth, R.A.; Yevich, S.M.; Vauthey, J.-N.; Odisio, B.C. Ablation of colorectal liver metastasis: Interaction of ablation margins and RAS mutation profiling on local tumour progression-free survival. Eur. Radiol. 2018, 28, 2727-2734. [CrossRef] [PubMed]

104. Odisio, B.C.; Yamashita, S.; Huang, S.Y.; Harmoush, S.; Kopetz, S.; Ahrar, K.; Chun, Y.S.; Conrad, C.; Aloia, T.A.; Gupta, S.; et al. Local tumour progression after percutaneous ablation of colorectal liver metastases according to RAS mutation status. Br. J. Surg. 2017, 104, 760-768. [CrossRef] [PubMed]

105. Shady, W.; Petre, E.N.; Vakiani, E.; Ziv, E.; Gonen, M.; Brown, K.T.; Kemeny, N.E.; Solomon, S.B.; Solit, D.B.; Sofocleous, C.T. Kras mutation is a marker of worse oncologic outcomes after percutaneous radiofrequency ablation of colorectal liver metastases. Oncotarget 2017, 8, 66117-66127. [CrossRef] [PubMed]

106. Jiang, B.-B.; Yan, K.; Zhang, Z.-Y.; Yang, W.; Wu, W.; Yin, S.-S.; Chen, M.-H. The value of KRAS gene status in predicting local tumor progression of colorectal liver metastases following radiofrequency ablation. Int. J. Hyperth. 2019, 36, 210-218. [CrossRef]

107. Karapetis, C.S.; Khambata-Ford, S.; Jonker, D.J.; O'Callaghan, C.J.; Tu, D.; Tebbutt, N.C.; Simes, R.J.; Chalchal, H.; Shapiro, J.D.; Robitaille, S.; et al. K-rasMutations and Benefit from Cetuximab in Advanced Colorectal Cancer. N. Engl. J. Med. 2008, 359, 1757-1765. [CrossRef]

108. Van Cutsem, E.; Köhne, C.-H.; Hitre, E.; Zaluski, J.; Chien, C.-R.C.; Makhson, A.; D’Haens, G.; Pintér, T.; Lim, R.; Bodoky, G.; et al. Cetuximab and Chemotherapy as Initial Treatment for Metastatic Colorectal Cancer. N. Engl. J. Med. 2009, 360, $1408-1417$. [CrossRef]

109. Amado, R.G.; Wolf, M.; Peeters, M.; Van Cutsem, E.; Siena, S.; Freeman, D.J.; Juan, T.; Sikorski, R.; Suggs, S.; Radinsky, R.; et al. Wild-TypeKRASIs Required for Panitumumab Efficacy in Patients With Metastatic Colorectal Cancer. J. Clin. Oncol. 2008, 26, 1626-1634. [CrossRef]

110. Yamashita, S.; Chun, Y.S.; Kopetz, S.; Vauthey, J. Biomarkers in colorectal liver metastases. Br. J. Surg. 2018, 105, 618-627. [CrossRef]

111. Datta, J.; Smith, J.J.; Chatila, W.K.; McAuliffe, J.C.; Kandoth, C.; Vakiani, E.; Frankel, T.L.; Ganesh, K.; Wasserman, I.; Lipsyc-Sharf, M.; et al. Coaltered Ras/B-raf and TP53 Is Associated with Extremes of Survivorship and Distinct Patterns of Metastasis in Patients with Metastatic Colorectal Cancer. Clin. Cancer Res. 2020, 26, 1077-1085. [CrossRef] [PubMed]

112. Kawaguchi, Y.; Kopetz, S.; Newhook, T.E.; De Bellis, M.; Chun, Y.S.; Tzeng, C.-W.D.; Aloia, T.A.; Vauthey, J.-N. Mutation Status of RAS, TP53, and SMAD4 is Superior to Mutation Status of RAS Alone for Predicting Prognosis after Resection of Colorectal Liver Metastases. Clin. Cancer Res. 2019, 25, 5843-5851. [CrossRef] [PubMed]

113. Yamashita, S.; Odisio, B.C.; Huang, S.Y.; Kopetz, S.; Ahrar, K.; Chun, Y.S.; Conrad, C.; Aloia, T.A.; Gupta, S.; Harmoush, S.; et al. Embryonic origin of primary colon cancer predicts survival in patients undergoing ablation for colorectal liver metastases. Eur. J. Surg. Oncol. 2017, 43, 1040-1049. [CrossRef] [PubMed]

114. Gu, Y.; Huang, Z.; Gu, H.; Gao, F.; Zhang, T.; Huang, S.; Huang, J. Does the Site of the Primary Affect Outcomes When Ablating Colorectal Liver Metastases with Radiofrequency Ablation? Cardiovasc. Interv. Radiol. 2018, 41, 912-919. [CrossRef]

115. Odisio, B.C.; Yamashita, S.; Huang, S.Y.; Kopetz, S.; Ahrar, K.; Mizuno, T.; Conrad, C.; Aloia, T.A.; Chun, Y.S.; Gupta, S.; et al. Impact of Prior Hepatectomy History on Local Tumor Progression after Percutaneous Ablation of Colorectal Liver Metastases. J. Vasc. Interv. Radiol. 2018, 29, 395-403.e1. [CrossRef] [PubMed]

116. Urbonas, T.; Anderson, E.M.; Gordon-Weeks, A.N.; Kabir, S.I.; Soonawalla, Z.; Silva, M.A.; Gleeson, F.; Reddy, S. Factors predicting ablation site recurrence following percutaneous microwave ablation of colorectal hepatic metastases. HPB 2019, 21, 1175-1184. [CrossRef]

117. Pulitano, C.; Bodingbauer, M.; Aldrighetti, L.; de Jong, M.C.; Castillo, F.; Schulick, R.D.; Parks, R.W.; Choti, M.A.; Wigmore, S.J.; Gruenberger, T.; et al. Liver Resection for Colorectal Metastases in Presence of Extrahepatic Disease: Results from an International Multi-institutional Analysis. Ann. Surg. Oncol. 2011, 18, 1380-1388. [CrossRef]

118. Mise, Y.; Kopetz, S.; Mehran, R.J.; Aloia, T.A.; Conrad, C.; Brudvik, K.W.; Taggart, M.W.; Vauthey, J.-N. Is Complete Liver Resection Without Resection of Synchronous Lung Metastases Justified? Ann. Surg. Oncol. 2015, 22, 1585-1592. [CrossRef]

119. Wang, X.; Sofocleous, C.T.; Erinjeri, J.P.; Petre, E.N.; Gonen, M.; Do, K.G.; Brown, K.T.; Covey, A.M.; Brody, L.A.; Alago, W.; et al. Margin Size is an Independent Predictor of Local Tumor Progression After Ablation of Colon Cancer Liver Metastases. Cardiovasc. Interv. Radiol. 2013, 36, 166-175. [CrossRef] [PubMed] 
120. Sotirchos, V.S.; Petrovic, L.M.; Gonen, M.; Klimstra, D.S.; Do, R.K.G.; Petre, E.N.; Garcia, A.R.; Barlas, A.; Erinjeri, J.P.; Brown, K.T.; et al. Colorectal Cancer Liver Metastases: Biopsy of the Ablation Zone and Margins Can Be Used to Predict Oncologic Outcome. Radiology 2016, 280, 949-959. [CrossRef]

121. Muratore, A.; Ribero, D.; Zimmitti, G.; Mellano, A.; Langella, S.; Capussotti, L. Resection Margin and Recurrence-Free Survival After Liver Resection of Colorectal Metastases. Ann. Surg. Oncol. 2010, 17, 1324-1329. [CrossRef]

122. Kaye, E.A.; Cornelis, F.H.; Petre, E.N.; Tyagi, N.; Shady, W.; Shi, W.; Zhang, Z.; Solomon, S.B.; Sofocleous, C.T.; Durack, J.C. Volumetric 3D assessment of ablation zones after thermal ablation of colorectal liver metastases to improve prediction of local tumor progression. Eur. Radiol. 2019, 29, 2698-2705. [CrossRef] [PubMed]

123. Mulder, B.G.S.; Hendriks, P.; Baetens, T.; Van Erkel, A.R.; Van Rijswijk, C.S.P.; Van Der Meer, R.W.; Van De Velde, C.J.H.; Vahrmeijer, A.L.; Mieog, J.S.D.; Burgmans, M.C. Quantitative margin assessment of radiofrequency ablation of a solitary colorectal hepatic metastasis using MIRADA RTx on CT scans: A feasibility study. BMC Med. Imaging 2019, 19, 71. [CrossRef]

124. Van Tilborg, A.A.; Scheffer, H.J.; Nielsen, K.; Van Waesberghe, J.H.T.; Comans, E.F.; Van Kuijk, C.; Tol, P.M.V.D.; Meijerink, M.R. Transcatheter CT Arterial Portography and CT Hepatic Arteriography for Liver Tumor Visualization during Percutaneous Ablation. J. Vasc. Interv. Radiol. 2014, 25, 1101-1111.e4. [CrossRef]

125. Puijk, R.S.; Nieuwenhuizen, S.; van den Bemd, B.A.; Ruarus, A.H.; Geboers, B.; Vroomen, L.G.; Muglia, R.; De Jong, M.C.; De Vries, J.J.; Scheffer, H.J.; et al. Transcatheter CT Hepatic Arteriography Compared with Conventional CT Fluoroscopy Guidance in Percutaneous Thermal Ablation to Treat Colorectal Liver Metastases: A Single-Center Comparative Analysis of 2 Historical Cohorts. J. Vasc. Interv. Radiol. 2020, 31, 1772-1783. [CrossRef] [PubMed]

126. Piccioni, F.; Poli, A.; Templeton, L.C.; Templeton, T.W.; Rispoli, M.; Vetrugno, L.; Santonastaso, D.; Valenza, F. Anesthesia for Percutaneous Radiofrequency Tumor Ablation (PRFA): A Review of Current Practice and Techniques. Local Reg. Anesth. 2019, 12, 127-137. [CrossRef]

127. Denys, A.; Lachenal, Y.; Duran, R.; Chollet-Rivier, M.; Bize, P. Use of High-Frequency Jet Ventilation for Percutaneous Tumor Ablation. Cardiovasc. Interv. Radiol. 2014, 37, 140-146. [CrossRef]

128. Puijk, R.S.; Plantes, V.Z.D.; Nieuwenhuizen, S.; Ruarus, A.H.; Vroomen, L.G.; De Jong, M.C.; Geboers, B.; Hoedemaker-Boon, C.J.; Thöne-Passchier, D.H.; Gerçek, C.C.; et al. Propofol Compared to Midazolam Sedation and to General Anesthesia for Percutaneous Microwave Ablation in Patients with Hepatic Malignancies: A Single-Center Comparative Analysis of Three Historical Cohorts. Cardiovasc. Interv. Radiol. 2019, 42, 1597-1608. [CrossRef] [PubMed]

129. Kim, K.H.; Yoon, Y.S.; Yu, C.S.; Kim, T.W.; Kim, H.J.; Kim, P.N.; Ha, H.K.; Kim, J.C. Comparative analysis of radiofrequency ablation and surgical resection for colorectal liver metastases. J. Korean Surg. Soc. 2011, 81, 25-34. [CrossRef]

130. Agcaoglu, O.; Aliyev, S.; Karabulut, K.; El-Gazzaz, G.; Aucejo, F.; Pelley, R.; Siperstein, A.E.; Berber, E. Complementary Use of Resection and Radiofrequency Ablation for the Treatment of Colorectal Liver Metastases: An Analysis of 395 Patients. World J. Surg. 2013, 37, 1333-1339. [CrossRef]

131. Ruers, T.; Punt, C.; Van Coevorden, F.; Pierie, J.; Borel-Rinkes, I.; Ledermann, J.A.; Poston, G.; Bechstein, W.; Lentz, M.A.; Mauer, M.; et al. Radiofrequency ablation combined with systemic treatment versus systemic treatment alone in patients with non-resectable colorectal liver metastases: A randomized EORTC Intergroup phase II study (EORTC 40004). Ann. Oncol. 2012, 23, 2619-2626. [CrossRef] [PubMed]

132. Tinguely, P.; Dal, G.; Bottai, M.; Nilsson, H.; Freedman, J.; Engstrand, J. Microwave ablation versus resection for colorectal cancer liver metastases-A propensity score analysis from a population-based nationwide registry. Eur. J. Surg. Oncol. 2020, 46, 476-485. [CrossRef]

133. Doan, K.T.; Việt, L.N.; Tien, T.N.; Canh, B.N.; Thi, H.N.; Thanh, N.N.; Quang, B.B.; Le Van, Q.; Lee, H.W.; Hong, B.M. Prognostic Factors of Radiofrequency Ablation plus Systemic Chemotherapy for Unresectable Colorectal Cancer with Liver Metastasis. Int. J. Hepatol. 2020, 2020, 8836922. [CrossRef]

134. Engstrand, J.; Nilsson, H.; Jansson, A.; Isaksson, B.; Freedman, J.; Lundell, L.; Jonas, E. A multiple microwave ablation strategy in patients with initially unresectable colorectal cancer liver metastases-A safety and feasibility study of a new concept. Eur. J. Surg. Oncol. 2014, 40, 1488-1493. [CrossRef]

135. Evrard, S.; Rivoire, M.; Arnaud, J.; Lermite, E.; Bellera, C.; Fonck, M. Unresectable colorectal cancer liver metastases treated by intraoperative radiofrequency ablation with or without resection. Br. J. Surg. 2012, 99, 566. [CrossRef]

136. Van Tilborg, A.A.; Meijerink, M.R.; Sietses, C.; Van Waesberghe, J.H.; Mackintosh, M.; Meijer, S.; Van Kuijk, C.; Tol, P.V.D. Long-term results of radiofrequency ablation for unresectable colorectal liver metastases: A potentially curative intervention. $\mathrm{Br}$. J. Radiol. 2011, 84, 556-565. [CrossRef]

137. Nielsen, K.; Scheffer, H.J.; Volders, J.H.; Van Der Vorst, M.J.; Van Tilborg, A.A.; Comans, E.F.; Klerk, E.S.M.D.L.-D.; Sietses, C.; Meijer, S.; Meijerink, M.R.; et al. Radiofrequency Ablation to Improve Survival After Conversion Chemotherapy for Colorectal Liver Metastases. World J. Surg. 2016, 40, 1951-1958. [CrossRef] [PubMed]

138. Tanaka, K.; Adam, R.; Shimada, H.; Azoulay, D.; Lévi, F.; Bismuth, H. Role of neoadjuvant chemotherapy in the treatment of multiple colorectal metastases to the liver. Br. J. Surg. 2003, 90, 963-969. [CrossRef]

139. Dijkstra, M.; Nieuwenhuizen, S.; Puijk, R.S.; Geboers, B.; Timmer, F.E.F.; Schouten, E.A.C.; Scheffer, H.J.; de Vries, J.J.J.; Ket, J.C.F.; Versteeg, K.S.; et al. The Role of Neoadjuvant Chemotherapy in Repeat Local Treatment of Recurrent Colorectal Liver Metastases: A Systematic Review and Meta-Analysis. Cancers 2021, 13, 378. [CrossRef] [PubMed] 
140. Siperstein, A.E.; Berber, E.; Ballem, N.; Parikh, R.T. Survival After Radiofrequency Ablation of Colorectal Liver Metastases: 10-year experience. Ann. Surg. 2007, 246, 559-567. [CrossRef] [PubMed]

141. Hof, J.; Wertenbroek, M.W.; Peeters, P.M.; Widder, J.; Sieders, E.; de Jong, K.P. Outcomes after resection and/or radiofrequency ablation for recurrence after treatment of colorectal liver metastases. Br. J. Surg. 2016, 103, 1055-1062. [CrossRef] [PubMed]

142. Valls, C.; Ramos, E.; Leiva, D.; Ruiz, S.; Martinez, L.; Rafecas, A. Safety and Efficacy of Ultrasound-Guided Radiofrequency Ablation of Recurrent Colorectal Cancer Liver Metastases after Hepatectomy. Scand. J. Surg. 2015, 104, 169-175. [CrossRef] [PubMed]

143. Fan, X.-X.; Lv, S.-Y.; Zhang, M.-W.; Dai, X.-Y.; Zhao, J.-P.; Mao, D.-F.; Zhang, Y. Clinical analysis of ultrasound-guided radiofrequency ablation for recurrent colorectal liver metastases after hepatectomy. World J. Surg. Oncol. 2020, 18, 76-79. [CrossRef] [PubMed]

144. Mao, R.; Zhao, J.; Bi, X.; Zhang, Y.; Han, Y.; Li, Z.; Zhao, H.; Cai, J. Resectable recurrent colorectal liver metastasis: Can radiofrequency ablation replace repeated metastasectomy? ANZ J. Surg. 2019, 89, 908-913. [CrossRef] [PubMed]

145. Faitot, F.; Faron, M.; Adam, R.; Elias, D.; Cimino, M.; Cherqui, D.; Vibert, E.; Castaing, D.; Cunha, A.S.; Goéré, D. Two-Stage Hepatectomy Versus 1-Stage Resection Combined With Radiofrequency for Bilobar Colorectal Metastases: A case-matched analysis of surgical and oncological outcomes. Ann. Surg. 2014, 260, 822-828. [CrossRef] [PubMed]

146. Van Amerongen, M.; van der Stok, E.; Fütterer, J.; Jenniskens, S.; Moelker, A.; Verhoef, C.; Grünhagen, D.; de Wilt, J. Results after simultaneous surgery and RFA liver ablation for patients with colorectal carcinoma and synchronous liver metastases. Eur. J. Surg. Oncol. 2019, 45, 2334-2339. [CrossRef] [PubMed]

147. Mizuno, T.; Cloyd, J.M.; Omichi, K.; Chun, Y.S.; Conrad, C.; Tzeng, C.-W.D.; Wei, S.H.; Aloia, T.A.; Vauthey, J.-N. Two-Stage Hepatectomy vs One-Stage Major Hepatectomy with Contralateral Resection or Ablation for Advanced Bilobar Colorectal Liver Metastases. J. Am. Coll. Surg. 2018, 226, 825-834. [CrossRef]

148. Hof, J.; Joosten, H.J.; Havenga, K.; De Jong, K.P. Radiofrequency ablation is beneficial in simultaneous treatment of synchronous liver metastases and primary colorectal cancer. PLoS ONE 2018, 13, e0193385. [CrossRef]

149. Sasaki, K.; Margonis, G.A.; Andreatos, N.; Kim, Y.; Wilson, A.; Gani, F.; Amini, N.; Pawlik, T.M. Combined resection and RFA in colorectal liver metastases: Stratification of long-term outcomes. J. Surg. Res. 2016, 206, 182-189. [CrossRef]

150. Eltawil, K.M.; Boame, N.; Mimeault, R.; Shabana, W.; Balaa, F.K.; Jonker, D.J.; Asmis, T.R.; Martel, G. Patterns of recurrence following selective intraoperative radiofrequency ablation as an adjunct to hepatic resection for colorectal liver metastases. $J$. Surg. Oncol. 2014, 110, 734-738. [CrossRef]

151. Meijerink, M.R.; Puijk, R.S.; Van Tilborg, A.; Henningsen, K.H.; Fernandez, L.G.; Neyt, M.; Heymans, J.; Frankema, J.S.; De Jong, K.P.; Richel, D.J.; et al. Radiofrequency and Microwave Ablation Compared to Systemic Chemotherapy and to Partial Hepatectomy in the Treatment of Colorectal Liver Metastases: A Systematic Review and Meta-Analysis. Cardiovasc. Interv. Radiol. 2018, 41, 1189-1204. [CrossRef] [PubMed]

152. Tanaka, K.; Shimada, H.; Nagano, Y.; Endo, I.; Sekido, H.; Togo, S. Outcome after hepatic resection versus combined resection and microwave ablation for multiple bilobar colorectal metastases to the liver. Surgery 2006, 139, 263-273. [CrossRef] [PubMed] 